\title{
A Phytogeographical Classification of the North American Pacific Coast Based on Climate, Vegetation and a Floristic Analysis of Vascular Plants
}

\author{
Manuel Peinado, ${ }^{1}$ Miguel Ángel Macías, ${ }^{2}$ Juan Luis Aguirre, ${ }^{3}$ and José Delgadillo ${ }^{4}$ \\ ${ }^{1}$ Departamento de Biología Vegetal, Universidad de Alcalá, 28871 Alcalá de Henares, Madrid, Spain \\ ${ }^{2}$ Departamento de Ciencias Ambientales, Universidad de Guadalajara, 44281 Guadalajara, JAL, Mexico \\ ${ }^{3}$ Cátedra de Medio Ambiente, Universidad de Alcalá, 28871 Alcalá de Henares, Madrid, Spain \\ ${ }^{4}$ Universidad Autónoma de Baja California, 22860 Ensenada, BC, Mexico
}

Correspondence should be addressed to Manuel Peinado, manuel.lorca@uah.es

Received 7 February 2009; Accepted 8 May 2009

Recommended by David L. Dilcher

This study was designed to explore floristic variation along the Pacific coast from Cook Inlet, Alaska, to the southern tip of Baja California, Mexico. Data corresponding to 965 phytosociological relevés (including 686 vascular plants) obtained by sampling 279 coastal sites were examined. Using an objective classification system (Average Linkage Clustering), floristic data acquired in fieldwork were related to the macroclimates of the study area. The registered taxa were grouped into phytogeographical elements, giving rise to a phytogeographical classification in which eight floristic provinces were distinguished. Floristic differences among provinces were correlated with palaeoclimatic and palaeogeographical events. The boreal and temperate provinces show high percentages of broadly distributed elements, whose origins can be found in the Boreotropical or Arcto-Tertiary geoflora that dominated the Northern Hemisphere during the Tertiary. The floristically richest provinces are the three that occupy the Mediterranean zone, since these provinces harbour elements of Arcto-Tertiary and Madro-Tertiary geofloras. The flora of tropical Baja California is characterised by a high number of taxa related to Neotropical flora, especially to those showing links with South America.

Copyright (c) 2009 Manuel Peinado et al. This is an open access article distributed under the Creative Commons Attribution License, which permits unrestricted use, distribution, and reproduction in any medium, provided the original work is properly cited.

\section{Introduction}

This paper presents a phytogeographical classification of the Pacific Coast of North America mainly based on the floristic analysis of azonal coastal vegetation types. As considered here, azonal vegetation types are those influenced to a greater extent by the soil than by climate [1], and include typical coastal vegetation types such as those inhabiting lithobiomes (ocean-facing cliffs), psammobiomes (beaches and dunes), halobiomes (saltmarshes and areas of vegetation types influenced in greater or lesser measure directly by exposure to air-borne salts) and amphibiomes (wetlands).

Since the times of Humboldt, plant geographers have been aware of species range restrictions, recognizing that plant species can be grouped on the basis of similarities among their geographic distributions [2]. Taxa within a study area are classified into floristic groups based on simi- larities in their worldwide geographical distributions [3]. Such floristic assemblages have been generally termed "areal types" [4], "floristic groups" [5], "geographical elements" [3], or "phytogeographical elements" [6]. One of the principal objectives of biogeography is the identification and classification of floristic elements and their corresponding areas [7].

In a previous study [8] we performed an analysis of the zonobiomes and zonoecotones of the North American Pacific, from Baja California to Alaska. The present study was based on the results of this study but was specifically designed to explore floristic variation with the ultimate aim of generating a phytogeographical classification scheme up to the province level through the definition of phytogeographic elements. With the exception of the use of fauna as a classification factor, the division into provinces presented in this article attempts to follow Dice's criterion of considering 
provinces as reasonably discrete areas with characteristic physiography, climate, vegetation, flora, and fauna [9], a definition also applied with some modification in the classification schemes of Peinado et al. [10], Bailey [11], Brown et al. [12], and Rivas-Martínez et al. [13].

\section{Study Area}

Overlooking the Pacific Ocean, the study area extends over $7000 \mathrm{~km}$ from southwestern Alaska $\left(61^{\circ} 30^{\prime} \mathrm{N}\right)$ to Baja California, where the southernmost site was sampled at $23^{\circ} 02^{\prime} \mathrm{N}$. In longitude, the area reaches its western limit on Kodiak Island, at $152^{\circ} 34^{\prime} \mathrm{W}$, while the easternmost site sampled was $109^{\circ} 34^{\prime} \mathrm{W}$, in Bahía de Las Palmas, Baja California Sur (Figure 1). The whole area forms part of the largest and highest of North American physiographic systems, the Pacific Border System [14], which is the backdrop for most of the ocean's shores.

Four zonobiomes (ZBs) can be distinguished along this latitudinal band: boreal (ZB-VIII), warm-temperate (ZB-V), Mediterranean (ZB-IV), and ZB-III or subtropical arid. Two transitional zones or zonoecotones (ZEs) occur between the California-Oregon border (ZE-IV/V) and around $30^{\circ}$, near El Rosario, Baja California (ZE-IV/III). These zonoecotones show a marked floristic and endemic richness $[8,17]$.

\section{Materials and Methods}

This study was based on a floristic analysis of vascular flora recorded at 279 sites along the Pacific coast, including the islands Kodiak and Vancouver (Figure 2; see [8, Appendix 1] for site locations). The aim of the fieldwork was to draw up lists of plants for each site and evaluate the significance of each plant in their respective habitat. To this end, habitats were differentiated in each site on the basis of physical features, the physiognomy and structure of the vegetation, and species dominance. In each habitat, we selected a plot of size based on the concept of the minimum area of relatively uniform stands [18]. Phytosociological relevés were taken in each plot according to the Braun-Blanquet approach [15]. 965 relevés were conducted comprising 381 genera and 686 infrageneric taxa.

With the data obtained in the field, a double entry matrix (sites and species) was constructed, in which the cover/abundance values of the Braun-Blanquet scale were transformed into a binary scale of presence (value 1) or absence (value 0). This matrix was used to classify the data using SPSS v13.0 software, starting with a matrix that included each plant recorded in the relevés, together with their respective values. Classification was based on square Euclidean distances calculated by an Average Linkage Clustering (ALC) method of similarity. ALC is one of the most frequently used methods in vegetation similarity analysis, in which the process of fusion is based on the minimum average distance between individuals and groups. The advantages of the ALC over single or complete linkage clustering were summarized by Peinado et al. [19].

The next step was to recompile the information available for the distribution area of each taxon recorded in the field.
To do this, bibliographical sources were used (see [8] for data sources) along with distribution maps obtained from the 2008 version of the USDA database. According to their distribution areas, the registered taxa were distributed in phytogeographical elements (Table 1). Plant nomenclature usually follows USDA [20], except for Bajacalifornian taxa [21], Agave [22], Helianthus [23], and Isocoma [24]. For genera see Wielgorskaya [25].

Finally, the sampled sites were assigned to a meteorological station according to their geographical proximity. Every station was classified using the bioclimatic system of RivasMartínez [16]. Thus, sites were then assigned to a particular climate: Boreal, Temperate, Mediterranean, or Tropical.

\section{Results and Discussion}

The cluster diagram obtained using the matrix of 279 sites is shown in Figure 3. This initial site classification separated six large groups. According to the geographic location of the sites and their assignment to a climate, four of the groups correspond each to a climate zone (Boreal, Temperate, Mediterranean, or Tropical) and two groups to transition zones or zonoecotones (ZEC-1 and ZEC-2). These four climate groups were, in turn, divided into subgroups. To identify the floristic composition of these groups and subgroups, a synthetic table was created by scoring species as presence percentages in each group and subgroup. A summary of this table showing the most significant differences among subgroups is provided as Table 2, whereas Tables 3 and 4 show the phytogeographical elements grouping plants of each climate zone and cluster subgroups.

Tables 5 to 8 reflect main floristic differences between adjacent climate zones. These summary tables only provide data corresponding to the most significant coastal plants. In these tables, the term "differential taxa" is used to refer to those plants that, without being endemic to a particular climatic or phytogeographic unit, serve to floristically differentiate it from a neighbouring unit lacking these differential taxa. Finally, Appendix A provides lists of 381 genera and 686 infrageneric taxa grouped by phytogeograhical elements.

4.1. Phytogeographical Elements. The percentage of cosmopolitan genera (Table 3) in the study area is three times the figure calculated for North America north of Mexico [6]. However, it has to be considered that certain extended habitats, if not exclusive to coasts (mainly salt marshes and wetlands), are particularly favourable for cosmopolitan or subcosmopolitan genera such as Agrostis, Calystegia, Carex, Eleocharis, Plantago, Schoenoplectus, Typha, and many others. The percentage of cosmopolitan species (Table 4) is much lower than the proportion of, genera, since these genera are represented by species of a more restricted distribution.

Many vegetation types in boreal, temperate, and Mediterranean climate zones of the study area are dominated or codominated by genera of mainly Holarctic distribution such as Alnus, Arctostaphylos, Betula, Calamagrostis, Lathyrus, Leymus, Picea, Puccinellia, or Salix. The number of Holarctic species only represents $4.8 \%$ of the entire flora, but this proportion increases to $23 \%$ in the boreal climate zone. 


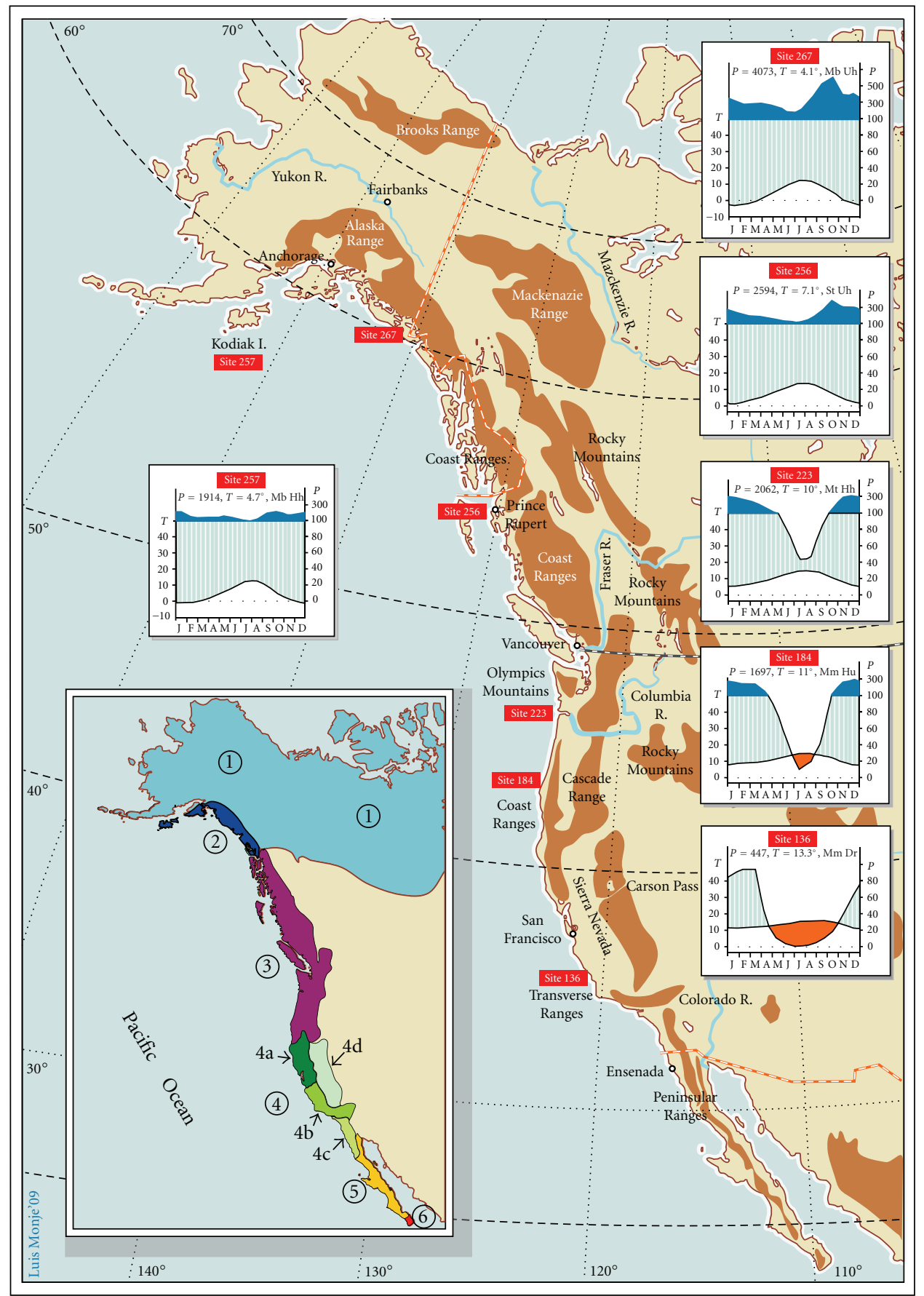

FIGURE 1: Physiographic map of the North American Pacific basin, climatograms for six sampled sites (see [8, Appendix 1], for site locations), and (lower left) phytogeographical units of the study area (after [15], modified): (1) Hudsonian province. (2) Sitkan province. (3) Oregonian province. (4) Californian region (Provinces: (4a) Northern Californian; (4b) Southern Californian; (4c) Martirense; (4d) Nevadian). (5) Baja Californian province. (6) Sanlucan province. Abbreviations for climatograms: Dr, Dry ombrotype; Hh, Hiperhumid ombrotype; Hu, Humid ombrotype; $\mathrm{Mb}$, Mesoboreal thermotype; Mm, Mesomediterranean thermotype; Mt, Mesotemperate thermotype; P, annual precipitation $(\mathrm{mm})$; St, Supratemperate thermotype; T, mean annual temperature $\left({ }^{\circ} \mathrm{C}\right)$; Uh, Ultrahiperhumid ombrotype. Thermotypes and ombrotypes according to Rivas-Martínez [16].

The proportion of Holarctic species decreases as latitude diminishes in boreal, temperate, and Mediterranean areas. There are no species of Holarctic distribution in the southern Mediterranean and tropical subgroups. One of the major characteristic features of the Holarctic element in the study area is the abundance of trees. We found 31 tree genera, 14 of which (45\%) belonged to the Holarctic element. In fact, most of these genera dominate much of the forested vegetation in boreal (Picea, Betula) and temperate (Picea, Salix) zones. The abundance of nemoral tall shrubs and forbs, which mostly inhabit forests, is also an outstanding feature of the Holarctic element, including genera such as Arctostaphylos, 


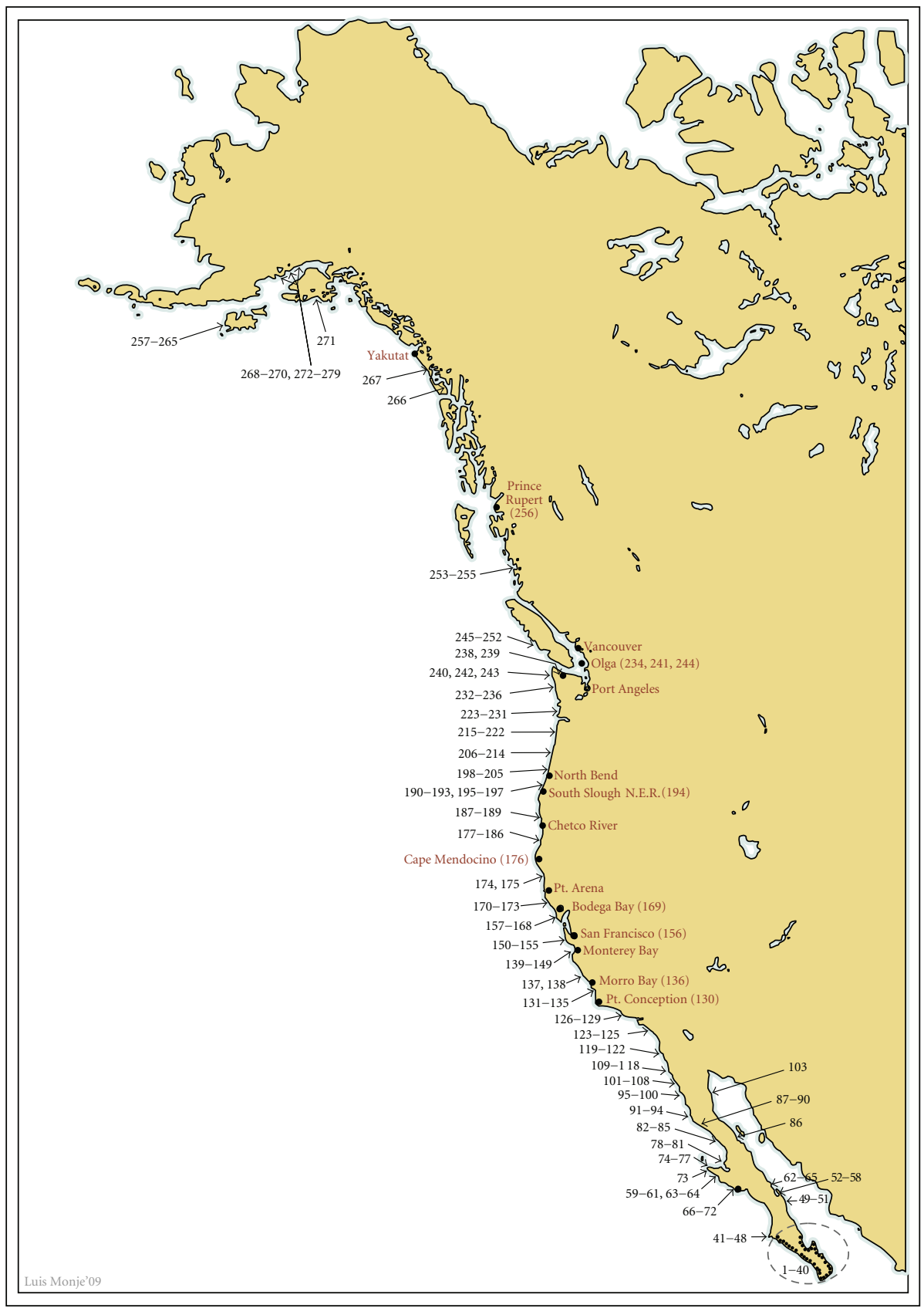

Figure 2: Location of the sites sampled (see [8, Appendix 1] for site locations) and climatograms for six of them. Abbreviations for climatograms: Ar, Arid ombrotype; Ha, Hiperarid ombrotype; T, mean annual temperature $\left({ }^{\circ} \mathrm{C}\right)$; Tm, Thermomediterranean thermotype; Tt, Thermotropical thermotype; P, annual precipitation ( $\mathrm{mm}$ ); Sa, Semiarid ombrotype; Thermotypes and ombrotypes according to RivasMartínez [16].

Corallorhiza, Cornus, Fritillaria, Linnaea, Listera, Lonicera, Maianthemum, Mertensia, Pyrola, Rhamnus, Rosa, Scrophularia and Vaccinium.

The Disjunct element encloses an important minor group of halophytic and desert genera (Arthrocnemum, Distichlis, Frankenia, Limonium, Sarcocornia, Spergularia, Suaeda and Triglochin). Further outstanding disjunct genera are Angelica (Holarctic and Australasia), Adenocaulon and Armeria (Holarctic and South America), Arbutus and Antirrhinum (Mediterranean basin and North America),
Empetrum (mainly Holarctic but also in South America and the Tristan da Cunha islands), Gaultheria and Lilaeopsis (America-Australia-New Zealand), Honkenya (Holarctic and coast of Patagonia), Myosurus (northern and southern temperate zones), Nicotiana (America-Australasia), Oligomeris (Holarctic and South Africa), and Pinus (Holarctic and Australasia).

Of the 17 North American-Eastern Asian genera, four are trees (Lithocarpus, Pseudotsuga, Thuja and Tsuga), the first two being especially important in forests of ZE-IV/V, and the 


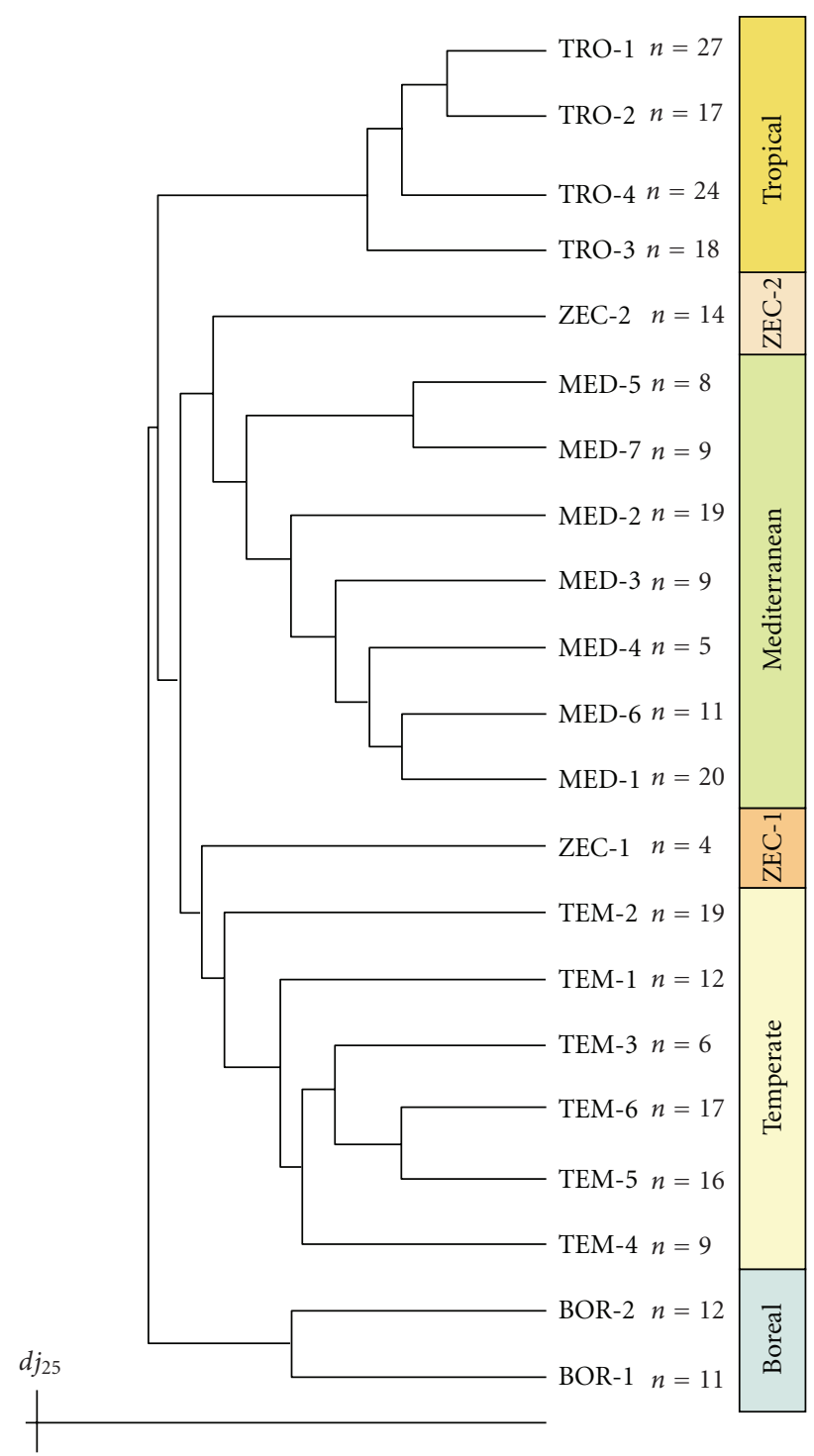

FIgure 3: Dendrogram yielded by Average Linkage Clustering of 279 sites. Abbreviations: BOR, boreal subgroups; MED: Mediterranean subgroups; $\mathrm{n}$, number of sites in each group and subgroup; TEM, temperate subgroups; TRO, tropical subgroups; ZEC, zonoecotone or transitional groups.

last two dominant in coastal woods of ZB-V. None of the genera of this element reach the tropical zone, and three extend as far as the boreal climate zone (Menziesia, Oplopanax and Tiarella), while largest numbers concentrate in the temperate and boreal zones. Only 13 species can be included in this element, because most North American-Eastern Asian genera are monospecific and their respective species are endemic to other phytogeographical elements. Most of these species are Amphiberingian taxa (see, [27]) such as Argentina egedii subsp. egedii, Deschampsia cespitosa subsp. beringensis (the most widely distributed taxon in this category, from southern Oregon to Alaska), Carex macrocephala (restricted to the temperate zone), Conioselinum gmelinii and Honkenya peploides subsp. major (boreal and temperate zones), and Carex ramenskii, Dendranthemaarcticum subsp. arcticum, Saussurea nuda, and Senecio pseudoarnica; these last three being exclusive to the boreal zone. A further 4 species (Angelica lucida, Cornus canadensis, Leymus mollis subsp. mollis, and Listera convallarioides) reach the North American Atlantic coast.

Most of the 41 North American-South American genera are restricted to southern Mediterranean and tropical climate zones. Only ten genera belonging to this element (Agoseris, Argentina, Baccharis, Camissonia, Cardionema, Grindelia, Holodiscus, Jaumea, Oenothera and Phacelia) reach the south of the temperate zone, and only one (Argentina) extends as far as the boreal coasts of Alaska. Seventeen species belong to this element; two are dominant or codominant on dunes of the Pacific coast, from the south of the Mediterranean climate zone to British Columbia: Ambrosia chamissonis (also present in the north of the tropical zone of Baja California), and Fragaria chiloensis subsp. pacifica. This last species and 
TABLE 1: Distribution ranges of the phytogeographical elements used in this work.

\begin{tabular}{|c|c|c|}
\hline & Phytogeographical element & Distribution range \\
\hline AAT & Amphi-Atlantic Tropical & Tropical zones of both Atlantic coasts \\
\hline APT & Amphi-Pacific Tropical & Tropical zones of both Pacific coasts \\
\hline BAJ & Bajacalifornian & Bajacalifornian and Sanlucan provinces (1) \\
\hline BOR & Boreal Northwestern Pacific & Boreal coasts of Alaska and British Columbia \\
\hline CAL & Californian & Californian Region (1) \\
\hline $\cos$ & Cosmopolitan & Ubiquitous \\
\hline DIS & Disjunct (only for genera) & Two o more separated phytogeographical regions (2) \\
\hline $\mathrm{HOL}$ & Holarctic & Holarctic Kingdom (3) \\
\hline INT & Introduced & Non-native taxa \\
\hline MAD & Madrean & Madrean Region (3) \\
\hline NAE & North American-Eastern Asian & Amphi-Pacific extratropical taxa \\
\hline NAS & North American-South American & Both Americas (excluding NEO taxa) \\
\hline $\mathrm{NEO}$ & Neotropical & Neotropical Kingdom \\
\hline $\mathrm{NOA}$ & North American & North America, including Greenland and Mexico \\
\hline PAC & Pacific & Pacific coast \\
\hline PAN & Pantropical & Pantropical taxa \\
\hline SON & Sonoran & Sonoran Province (4) \\
\hline TEM & Temperate Northwestern Pacific & Temperate coast between Oregon and British Columbia \\
\hline WES & Western North-American & West of the Rocky Mountains \\
\hline
\end{tabular}

(1) See Figure 1. (2) Excluding NAE, NAS, NEO and PAN genera. (3) Sensu Takhtajan [26]. (4) Sensu Takhtajan (l.c.), but excluding BAJ taxa.

Lathyrus japonicus var. maritimusare the only plants of this element that reach the coasts of Alaska.

There are only nine North American endemic genera, but some such as Ceanothus and Eriogonum are of considerable phytogeographic impact since they present several endemic species. There are 23 endemic genera in the Western North American element, some being significant for the coastal vegetation as dominant plants in dune communities: Abronia (tropical, Mediterranean and temperate foredunes), Ericameria and Eriophyllum (mainly Mediterranean and also reaching southern temperate dunes), Corethrogyne (Mediterranean dunes), and Wislizenia (tropical dunes).

There are no endemic genera in the Boreal Northwestern Pacific element. Some of its 13 infrageneric taxa are exclusive to coastal habitats, such as Atriplex alaskensis, A. drymarioides or Puccinellia hultenii, which appear in salt marshes and coastal mud flats, along with Ligusticum scoticum subsp. hultenii and Poa eminens, which are very characteristic of the beach vegetation. Others, on the contrary, appear to be essentially coastal although they may penetrate slightly inland, as is the case of Betula papyrifera var. kenaica, Castilleja unalaschcensis and Geranium erianthum (coastal forests). The Temperate Northwestern Pacific element lacks endemic genera and has only two endemic species: Grindelia integrifolia and Scrophularia oregana, both spreading from south Oregon to British Columbia. Other species of coastal habitats have their distribution areas restricted to the temperate zone, and also penetrate adjacent climatic zones.
These species distributed along the Pacific coast across more than one climatic zone, constitute the Pacific Coast element, in which 53 infrageneric taxa were included.

Madrean taxa are those occurring in both Mediterranean and tropical climate areas of the North American Southwest. Only one Madrean genus, Dudleya, penetrates slightly into the temperate zone of southern Oregon. The species in this element exclusively concentrate in the zones Mediterranean and Tropical, and highest proportions occur in the transitional groups ZEC-2, MED-7, and TRO-1. Only two of the twelve Californian genera, Sequoia and Umbellularia, penetrate into the southern temperate groups TEM-5 and TEM-6, while Aphanisma enters the northern tropical group TRO-1. The Californian element is the most outstanding in terms of its number of endemic species. This exceeds $40 \%$ in some southern subgroups that accommodate the largest number of endemisms of the whole Pacific coast, including the genera Bergerocactus, Cneoridium, Ornitostaphylos, and Xylococcus, almost endemic to Mediterranean Baja California. Eleven species of the Californian element appear in the Tropical group, all recorded in the northern region of the El Vizcaíno peninsula, just south of the boundary between the Mediterranean and tropical climate zones.

The Sonoran endemic element, centred in the desert areas of western North America, includes nine genera of wide distribution in the Sonoran province. One Sonoran endemic genus (Peucephyllum) was observed in the southern Mediterranean group MED-7 and two (Pachycereus and 


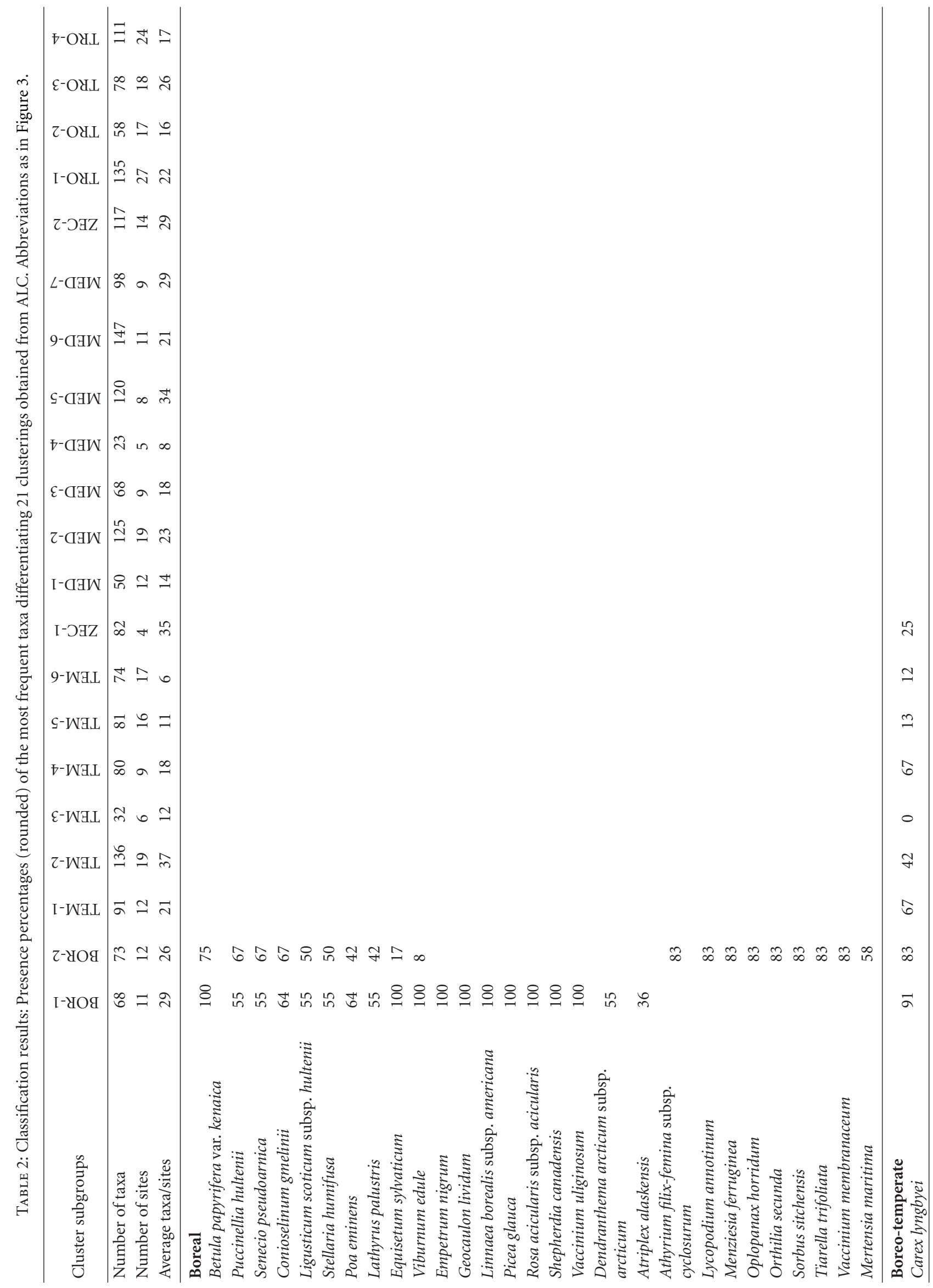




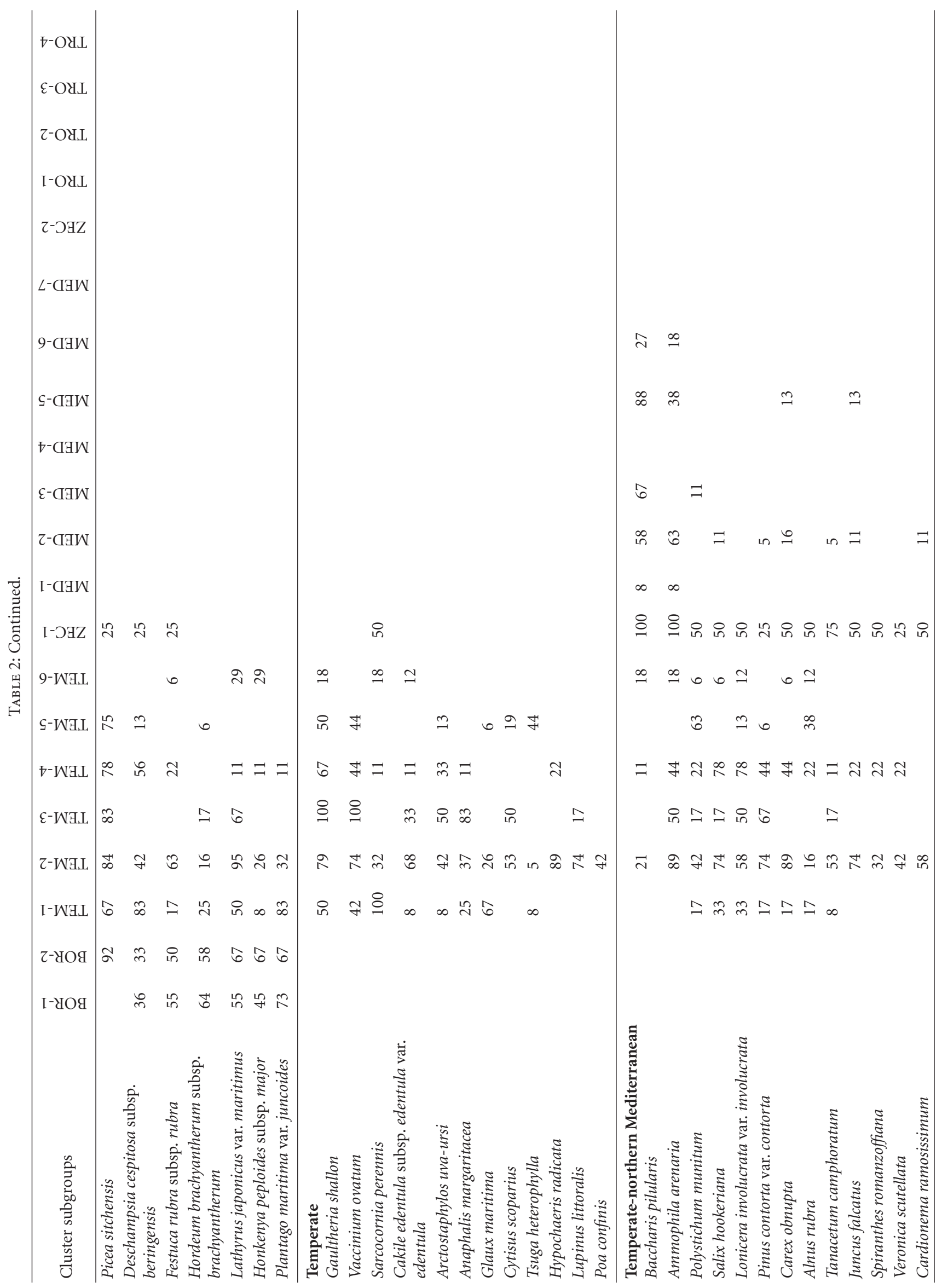




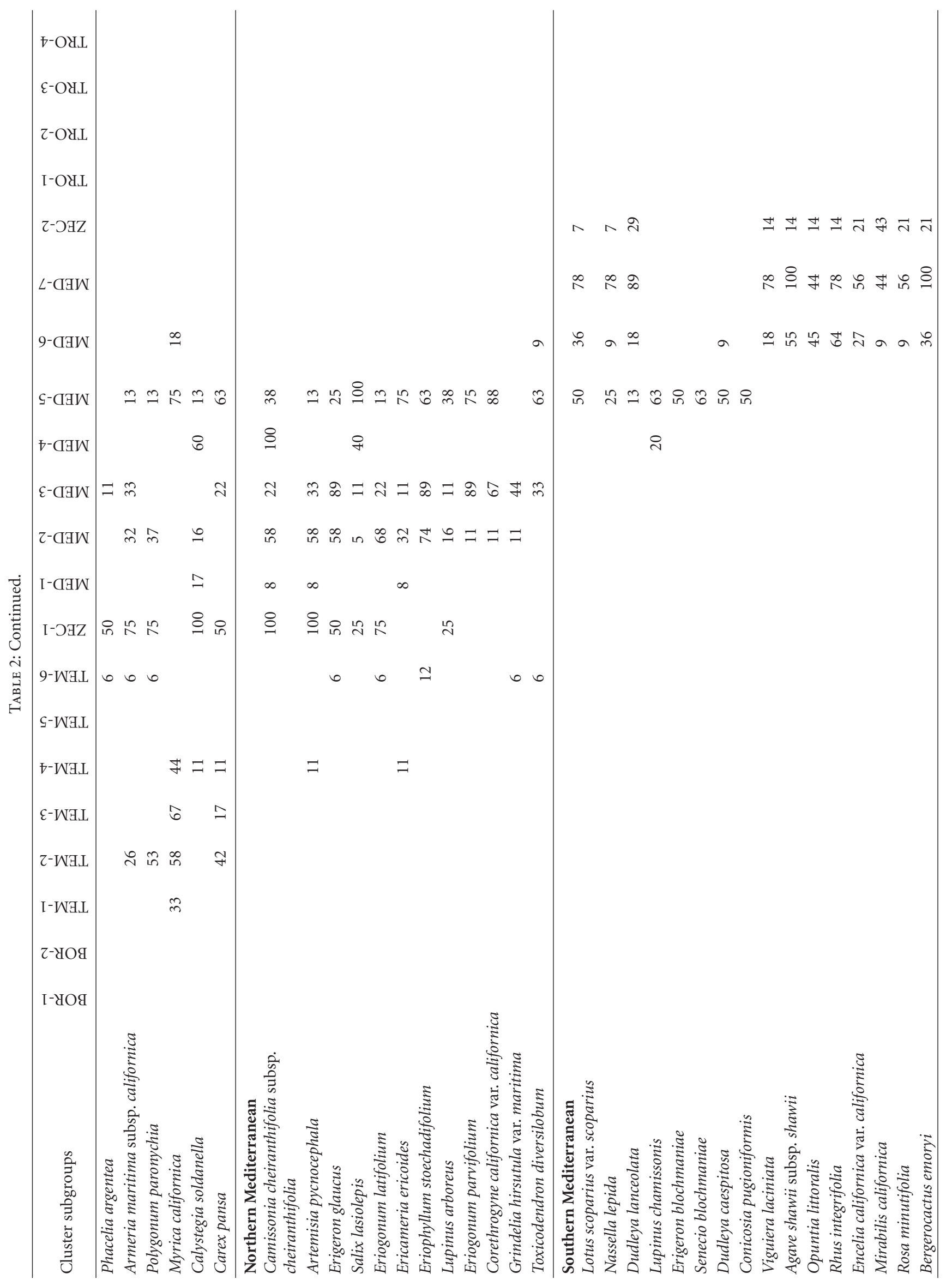




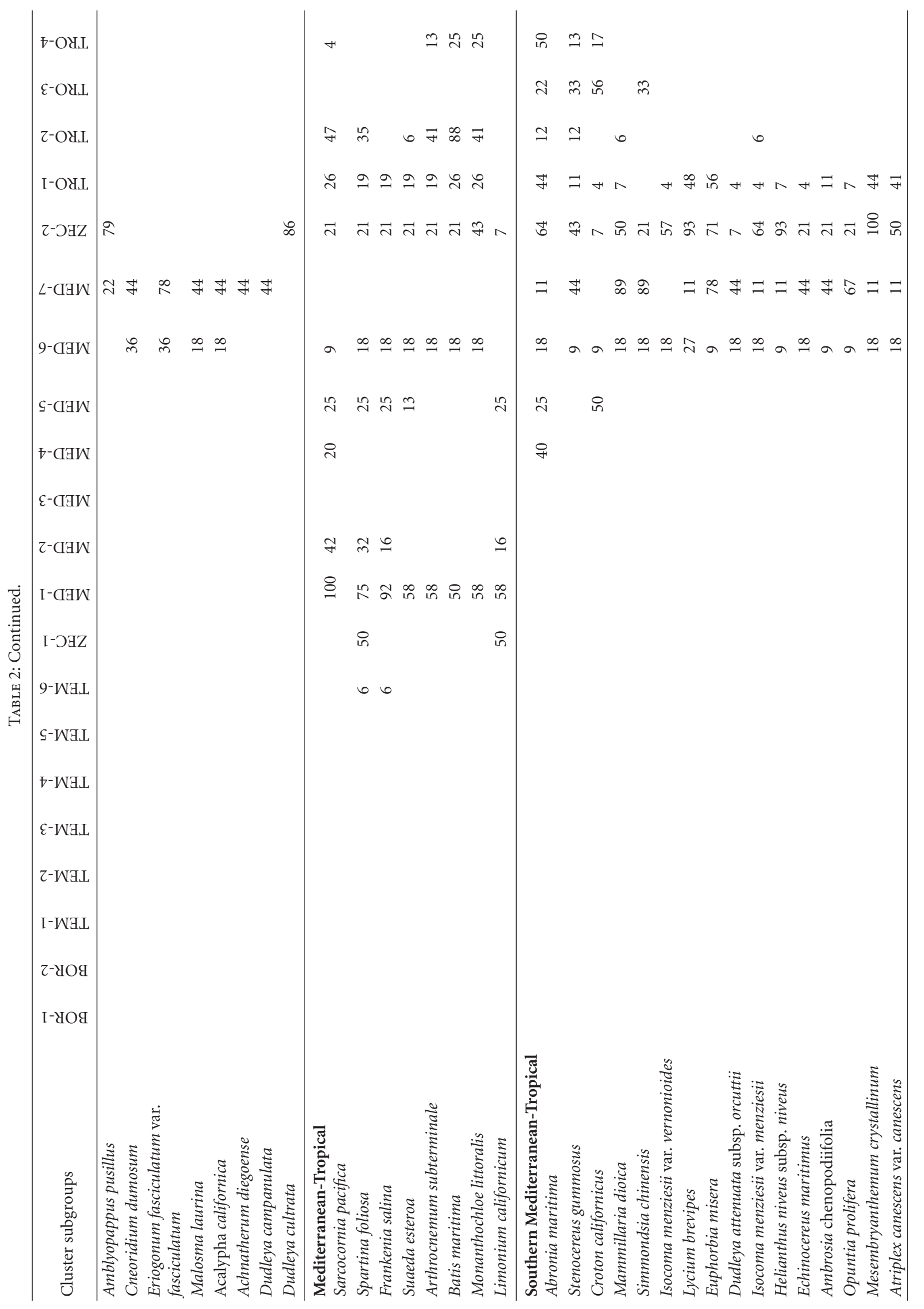




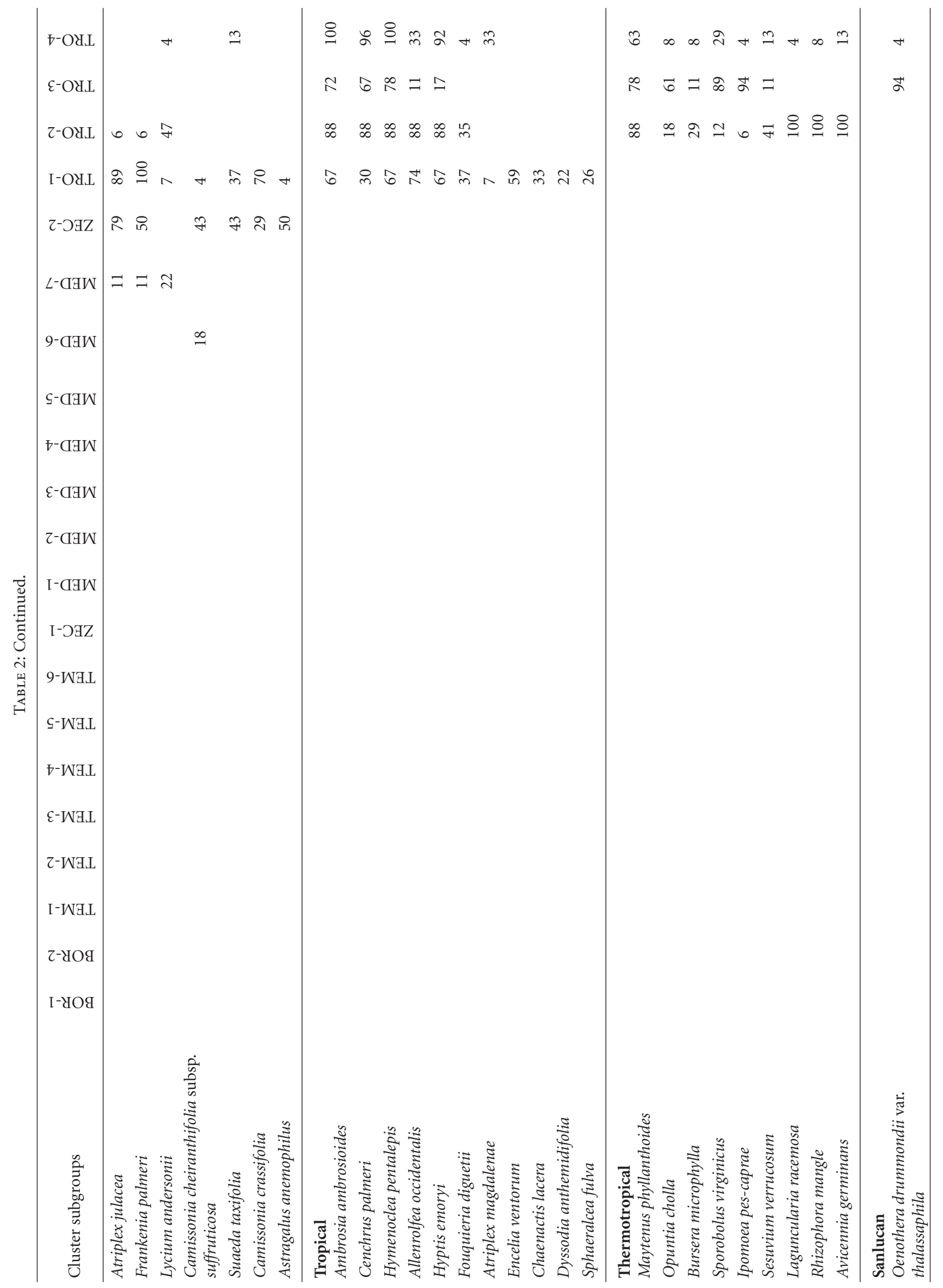




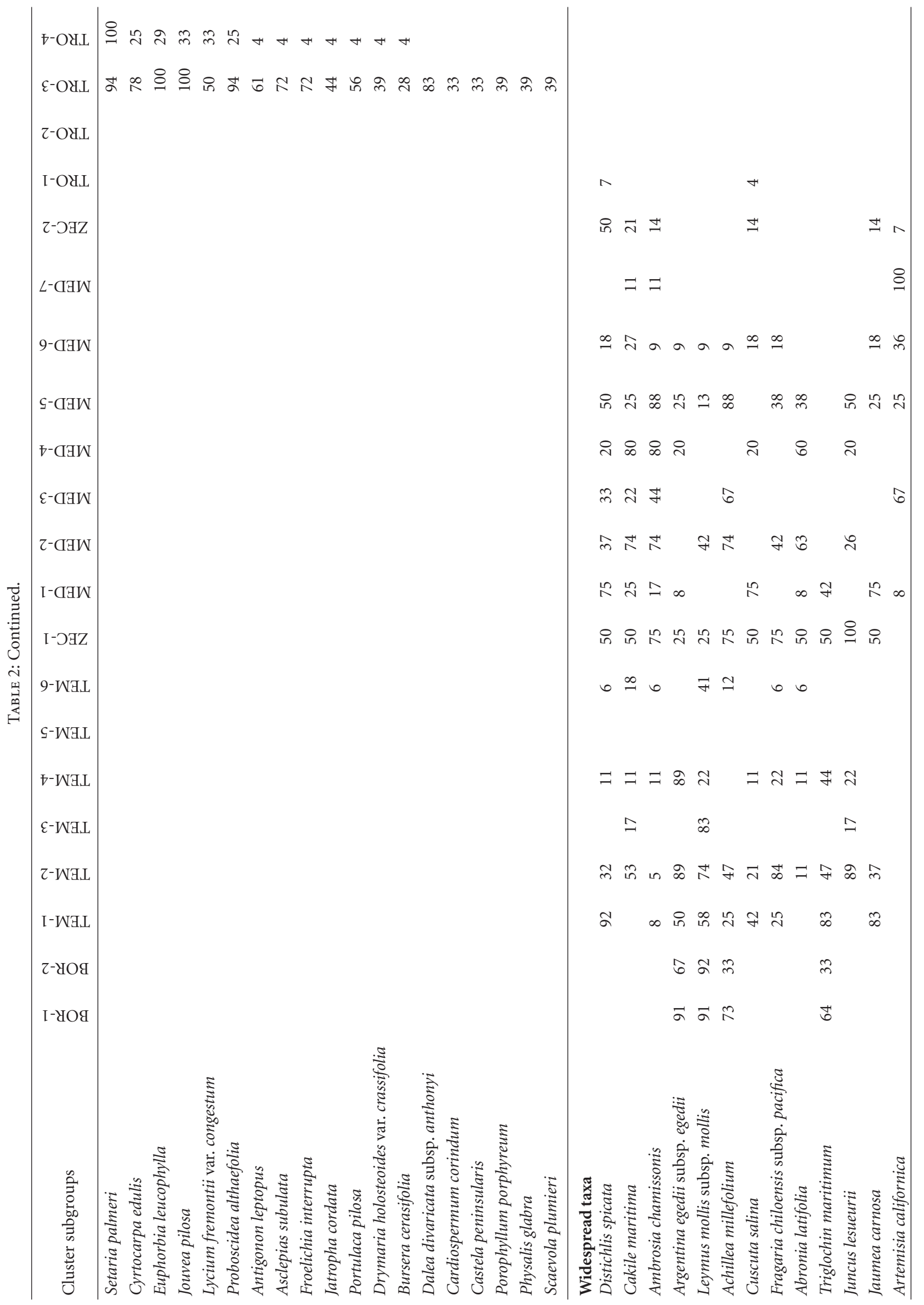




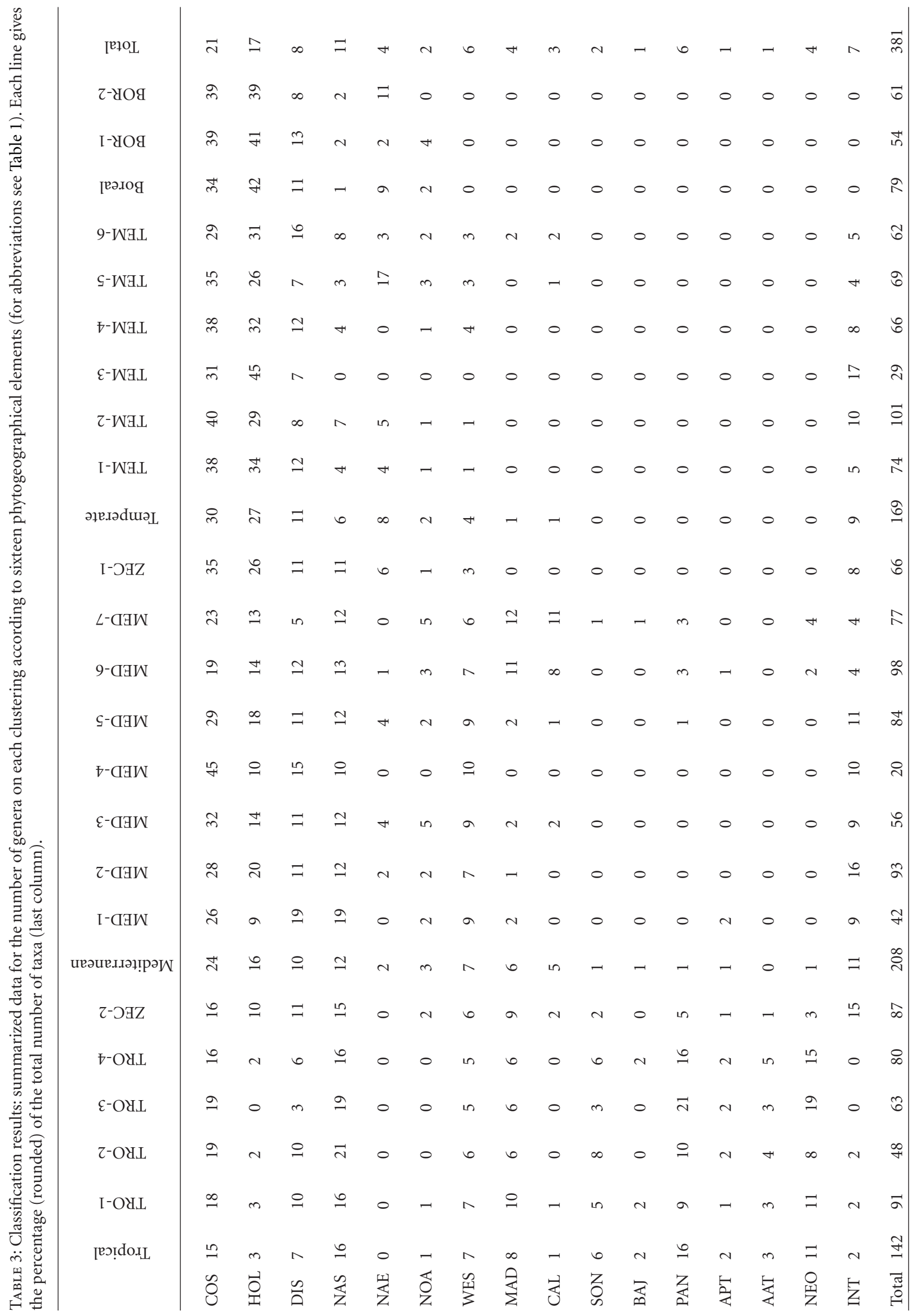




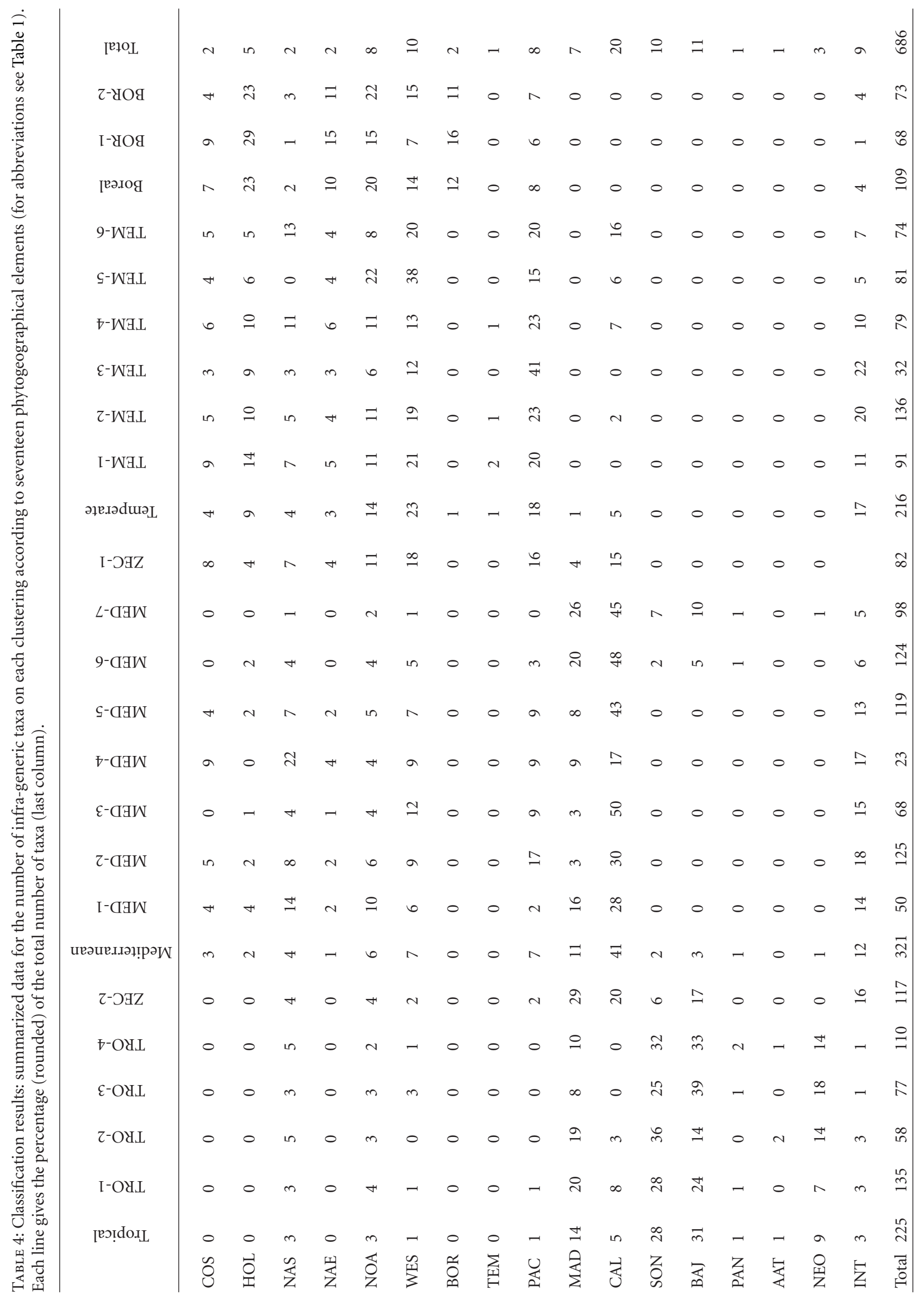


Peucephyllum) in the transition group ZEC-2. The 66 species showing a Sonoran distribution concentrate in the tropical climate zone, although some (e.g., Ambrosia chenopodiifolia, A. dumosa, Nolina parryi, Ferocactus cylindraceus, Stenocereus gummosus) penetrate a little into the southern Mediterranean zones of the transition groups MED-6, MED-7, and ZEC-2.

The Baja Californian element includes four monospecific genera and 78 species endemic to Baja California. Most of these species are restricted to the tropical climate zone, although some (Aesculus parryi, Cuscuta veatchii, Cynanchum peninsulare, Echinocereus maritimus, Harfordia macroptera, Myrtillocactus cochal, Rosa minutifolia, and Sarcostemma arenarium) also inhabit the zone of Mediterranean climate in northwestern Baja California. There are 48 genera exclusive to Tropical areas (AAT, APT, NEO, PAN), that is, which are found in each of the three tropical zones (Africa, America, and Asia-Australasia), excluding the Sonoran and Baja Californian tropical-desert areas. Of these 48 genera, two, Batis and Croton, appear outside the Baja California peninsula, although neither genus has been recorded north of Point Conception. At the species level, the Tropical elements include 26 species of wide tropical distribution such as Avicennia germinans, Conocarpus erecta, Jouvea pilosa, Laguncularia racemosa, or Rhizophora mangle. Along with the Sonoran and Baja Californian elements, the Tropical elements account for $24.7 \%$ of all species, concentrated mostly in the tropical climate zone of Baja California.

The number of introduced genera and species decreases toward the climatic extremes of the study area, attaining highest values in the temperate and Mediterranean zones, subjected to greatest human pressures. In some cases, as for the European marram grass, Ammophila arenaria, for Carpobrotus edulis, Spartina alterniflora, several species of the genus Bromus, or Mesembryanthemum crystallinum and M. nodiflorum, the importance of introduced species is the result of the intense changes they induced or still induce in some coastal ecosystems of the northern Pacific [28]. Twelve genera, such as Agrostis, Atriplex, Bromus, Cakile, Plantago, and Rumex or Spartina, are represented by introduced and native species. In these cases, we considered the genus as native and recorded the species as introduced or native in the corresponding category in Appendix A.

A close relationship also exists between the climatic distribution of the introduced species and their centres of origin. Species of the genera Bromus, Carpobrotus, Cytisus, or Mesembryanthemum, from other zones of Mediterranean climate in the world have been preferentially or exclusively introduced in the Mediterranean climate zone of North America. The genera Aira, Ammophila, Cakile, Holcus, Hypochaeris, or Ulex, from the temperate and Mediterranean zones of Europe, have become naturalized in the same climate zones of North America.

4.2. Phytogeographical Elements, Origins and Relationships among Northern Pacific Coastal Flora. In the study zone, 354 indigenous genera were recorded, of which 282 were genera shared with the flora of other continents. Of these 282 genera, 191 are shared with Eurasia-Africa and 189 with
South America. Although in some cases we cannot rule out dispersion models linked to water or air currents, or bird migration [29], it seems clear that we should look to the past to search for most of these intercontinental relationships linked to palaeoclimatic and palaeogeological events.

North America has never been isolated completely from the rest of the world, at least since $300 \mathrm{Ma}$, although it did separate from individual continents in different geological times [6]. Given that most angiosperm families and many genera arose and underwent diversification during the Cretaceous/Tertiary transition [30], intercontinental connections allowing the exchange of flowering plants must have existed at this stage or must have been subsequent to this epoch.

In the late Cretaceous, the Northern Hemisphere was colonized by two floras: Pacifis, which extended from the east of Asia to western North America, and Atlantis, covering the area from eastern North America to Europe [31]. Intercontinental connection was achieved by two land bridges: the North Atlantic bridge, between eastern North America and Europe, and the Bering bridge, between eastern Asia and western North America [32, 33]. Both these land connections allowed the ample transfer of plants between continents, although North America was divided by the Midcontinental Seaway, extending from the Gulf of Mexico to the Arctic, at least up until the start of the Tertiary, when its retreat northand southwards was to clear the way for intracontinental migration $[34,35]$.

Since the early Tertiary and over the following 40 million years, an equable warm climate affected the entire Northern Hemisphere [36], allowing the existence of the socalled Arcto-Tertiary [37] or Subtropical-Boreotropical [38] geoflora (the authors are aware of the limitations of the geoflora concept as originally defined, but for the purposes of this paper it provides a useful background for discussion; see [35, p. 106-109]. This geoflora formed a more or less continuous belt around the present Arctic and covered the current latitudes of almost all Eurasia and North America [36]. Fossil data show that many tree genera of the modern coastal flora (e.g., Alnus, Betula, Fraxinus, Quercus, or Rhus) also occurred in the boreotropical flora of North America and Eurasia [35, 39-41]. Phylogenetic, molecular, geologic, and fossil data all support the hypothesis that the eastern Asian and eastern North American disjunct distributions are relicts of the maximum development of temperate forests in the northern hemisphere during the Tertiary [42, 43]. Fossil and geologic evidence supports multiple origins of this pattern in the Tertiary, with both the North Atlantic and the Bering land bridges involved [44]. Intercontinental connections between Eurasia and North America would have continued well into the Eocene, with the disruption of the North Atlantic bridge [33] until as recent as some 10.000 years ago when the Bering land bridge finally disappeared [45]. Links with Africa were less significant, and leaving aside the ancient connection of the Pangaea supercontinent (c. $245 \mathrm{Ma}$ ) can be explained by two routes: one evoking the drying of the Mediterranean Sea during the Miocene [46], allowing intense exchange of species between Eurasia and Africa, and the other more ancient route, goes back to the Late Cretaceous, which saw the definitive separation of 
America from Africa [47], although there may have been a relatively easy migration route subsequent to this via chains of islands or via the Brazilian-Nigerian land bridge that persisted until the end of the Cretaceous [48].

Despite its current connection via the Isthmus of Panama, migrations between North America and South America have a more recent origin. North America and South America were joined from the end Carboniferous ( $c$. $300 \mathrm{Ma}$ ) until the Early Cretaceous (c. $120 \mathrm{Ma}$; [49]), that is, since before the diversification of the angiosperms. Since then and until the uplift of the Isthmus of Panama during the Mid-Pliocene, $3 \mathrm{Ma}$ ago [50, 51], North America and South America were separated by a large body of water that attained a distance of $3000 \mathrm{~km}$ [52]. The subsequent formation of the isthmus allowed the opening of the wellknown migratory corridor of Panama. This corridor has enabled the fluid migration of plants of tropical origin, from South America to North America, and of those of temperate origin in the reverse direction. This explains both the presence in South America of some taxa of Holarctic origin (Empetrum, Pyrola orVaccinium), having migrated across mountain tops following the Orogenic movements of the end Pliocene that uplifted the Cordillera [52-54], and the presence on the Pacific coast of basically tropical northern taxa including families such as Cactaceae, Fabaceae (Mimosoideae), Nyctaginaceae, or Zygophyllaceae, and genera such as Agave, Asclepias, Errazurizia, Gaultheria, Phoradendron, and so forth. However, considering the millions of birds that fly between North and South America every year, some transport of seeds seems probable, especially in communities such as those of seacoasts or seasonally moist places frequented by migratory birds. Seed dispersal by birds might explain the distribution along the entire Pacific coast of some coastal plants that presumably are self-compatible and autogamous: Amblyopappus pusillus, Ambrosia chamissonis, Crassula connata, Cardionema ramosissimum, Juncus lesueurii, Limonium californicum, or Sanicula crassicaulis [29]. Greatest concentrations of tropical flora occur on the coast of Baja California, a peninsula that separated from the continent during the Late Tertiary, around $3.6 \mathrm{Ma}$ ago [55], a time of intense specialisation of its flora, including 751 endemic taxa, of which 22 are endemic genera [10].

Of the 354 North American indigenous genera, 73 are North American endemics. Only nine of these extend from the Atlantic to the Pacific coast, while 64 thrive across the western half of North America, essentially from the Rocky Mountains to the Pacific. Of these 64 genera, 41 are southwestern endemics and 16 are endemics from Mediterranean California and Baja California, including genera that are local endemics of very small distribution area and almost restricted to coastal sites: Aphanisma, Bergerocactus, Cneoridium, Harfordia, Ornitostaphylos, Sequoia, and Xylococcus. At the species level, of the 521 North American endemics found in the study area, 251 (48.1\%) occur in the Mediterranean area including 142 Californian and Baja Californian endemics. The Mediterranean zone shows the highest level of endemics of the entire study area, consistent with global levels, since Mediterranean California and Baja
California have long been described as two important areas of biogeographical differentiation.

In the Mediterranean climate zone, there is interplay between mesic elements derived from Arcto-Tertiary geoflora and the xeric elements arising from Madro-Tertiary geoflora. The set of endemic taxa restricted to the southwest (Madrean, Californian and Baja Californian) is related to the Madro-Tertiary geoflora [37], whose existence is linked to climatic isolation, because the Mediterranean climate of southwestern North America only developed in the late Tertiary and this area has never been in direct contact with any other region of Mediterranean climate [56]. The existence of the taxa widely distributed in North America (North American and Western North American endemics), may be explained with the same argument presented for elements shared with Eurasia: their origins lie in the boreotropical or Arcto-Tertiary flora. Since the Oligocene, the warm climate that had characterized the Northern Hemisphere during the previous 40 million years turned colder in the Pliocene became intensely cold in the Pleistocene [33]. This temperature change had profound consequences on the Arcto-Tertiary flora, which underwent massive extinctions or migrations toward southern refugia. The Wisconsinian glaciations clearly affected all the temperate and boreal coastal zones, decimating the flora of lowlands, whose vegetation was replaced with a subalpine parkland comprising a mixture of lowland and montane trees such as $P$. sitchensis and $P$. contorta [57]. These were found in small pockets of unglaciated land [58] such as in the Queen Charlotte Islands, a glacial-age refugium [59]. The relatively high number of coastal boreal endemics (13) contrasts with the reduced number of species endemic to the Temperate Northwestern Pacific element (2). During the full-glacial conditions of 18.000 years ago, complexes of continental ice sheets dominated a good part of the land nowadays occupied by boreal and temperate vegetation [57]. However, since there were only local glaciers between the Tanana and Yukon rivers and in Central Yukon, a large refugium appeared in Alaska-Yukon [60]. This may have been crucial in determining the presence of relatively large number of endemics in boreal areas compared to temperate ones.

California is one of the most important areas of survival and persistence of relicts derived from the boreotropical flora $[38,61,62]$ because of equable maritime climate and because, since Late Pliocene times, the uplift of the Sierra Nevada-Cascade axis prevented the increasing aridity from spreading to coastal areas of mild or moderate climate [63]. The story for northwestern Baja California is even more remarkable. This Mediterranean corner of Baja California has about 1322 native vascular plants (Moran in [64]), 902 of which are not usually found in the rest of the peninsula; besides there are 633 genera, 292 of which do not exist elsewhere on the peninsula. Thus, this area, whose surface $\left(24,500 \mathrm{~km}^{2}\right)$ only constitutes $17 \%$ of the peninsular area, contains almost half of the species (44\%) and nearly three-quarters of the genera $(71 \%)$. On the other hand, approximately 227 species in northwestern Baja California are not found within the borders of California (Moran in 
[63]). The floristic richness of Baja California is mainly concentrated in its Mediterranean northwest.

The key to understanding this accumulation of diversity lies in the origin of the Baja Californian floristic elements. Based on floristic analysis, Peinado et al. [10] described northwestern Baja California as a place of refuge as much for taxa from the ancient Tertiary geoflora as for taxa from the Sonoran desert, which found a magnificent refuge from the climatic oscillations of the Late Wisconsinian glaciation along the Baja California coast. According to the terminology used by Stebbins and Major [65], the Mediterranean coastal zone of southern California and Baja California has high concentrations of palaeoendemics and neoendemics.

\subsection{Phytogeographical Classification (Figure 1)}

4.3.1. Boreal Climate Area (ZB-VIII): Hudsonian and Sitkan Provinces. The earliest phytogeographical treatment of the boreal climate area is that of Dice [9] who considered two provinces, one of continental boreal climate (Hudsonian) and another of oceanic boreal climate (Sitkan). All the sites of boreal climate occur in Alaska. When the sites in subgroup BOR-1 are projected onto a map, they clearly take up positions across Cook Inlet, a continental boreal area that lacks Picea sitchensis and where Hudsonian forests dominated by white spruce, Picea glauca, reach the Pacific Ocean $[9,11]$, sustaining endemic or exclusive plants that are absent from the BOR-2 subgroup (Table 4). The sites of subgroup BOR-2 extend along the open coast of the Pacific, under an oceanic boreal climate and across an area without Picea glauca and where woods of Picea sitchensis dominate the coast, characterizing the flora of the Sitkan province.

Sitka spruce is the present-day dominant tree along the coast, on the most foggy and rainy coasts of the Sitkan and Oregonian provinces from the Gulf of Alaska to the northwestern corner of California. Despite the common floristic background of these coastal forests there are also significant floristic differences between the oceanic boreal and temperate coastal forests. The former belong to the association Lycopodium annotinum-Tsuga mertensiana and the latter to the association Poystichum munitum-Picea sitchensis [66]. The absence of coastal shore pine forests in boreal areas is another difference between boreal and temperate coasts, while woods of Picea glauca and its associated flora are characteristic of the boreal zone [8].

4.3.2. Temperate Climate Area $(Z B-V)$ : Oregonian Province. Many classification schemes $[8,11-13,66-68]$ coincide in distinguishing floristic or ecological units replaced at the latitude of Dixon Entrance $\left(54^{\circ} 20^{\prime} \mathrm{N}\right)$, approximately at the northern limit of British Columbia, where Dice located the border between the boreal Sitkan and the temperate Oregonian provinces. The sites between northern British Columbia and southern Oregon, that is, in the $\mathrm{ZB}-\mathrm{V}$, clustered as a single group. These sites are in the Oregonian province $[9,12,67]$, also called Cascade province [13]. Peinado et al. [8] described the floristic changes occurring in the vegetation of beaches, dunes, sea-facing cliffs, saltmarshes, and climax forests that delineate the phytogeographic boundary between
ZB-V and ZB-IV, which coincides with the limits between the Oregonian province and the Californian region.

\subsubsection{Mediterranean Climate Area: Northern Californian,} Southern Californian and Martirense Provinces. There are 94 sites linked to Mediterranean meteorological stations, most of which gathered together in the Mediterranean cluster, which is floristically the best differentiated group. Raven et al. [63] calculated that Mediterranean California harbours 2,133 endemic vascular plants ( $48 \%$ of its entire flora). The number of Californian endemics recorded in the narrow band of coastal vegetation of the MED group amounts to $40.8 \%$ and reaches $50 \%$ in MED-3 (Table 4). The number of endemic genera is also outstanding (Table 3 ). More than $50 \%$ of the Californian endemics recorded are "maritime endemics," that is, restricted to coastal habitats, and with rare exceptions, the rest penetrate slightly inland.

Most classification schemes concur that the entire Mediterranean zone of California should be considered a phytogeographical unit well characterized in floristic and climatic terms. The floristic individuality of Mediterranean California has been repeatedly highlighted (see [63]) since the first phytogeographic works of Abrams [61]. The origin of the flora of California and isolation of the Mediterranean climate zone of the North American southwest since Tertiary times (see [69] for a review) also support the phytogeographical individuality of Mediterranean California.

Peinado et al. [10] divided the Mediterranean zone of western North America into three phytogeographical provinces (Figure 1): Northern Californian (from southwestern Oregon to Point Conception), Southern Californian (from Point Conception to San Diego County, near the international border), and Martirense (from San Diego to El Rosario, Baja California). These divisions are supported by floristic and vegetation data [8] and by our analysis of the endemic component (Table 8). There are two large distribution areas of Californian endemics: the coast of California (in turn divided into two subareas) and the coast of northwestern Baja California, including the neighbouring coast of San Diego County. 96 of the Californian endemics have their distribution areas within the state of California. 21 of them penetrate slightly into southern Oregon and 42 penetrate into northwestern Baja California. Of the 96 Californian endemics recorded on the coast of California, 42 show a southern distribution area that does not extend beyond Monterey Bay, such that they may be considered differential taxa of the Southern Californian province with regard to the Northern Californian province. 16 of these 42 southern taxa fail to reach San Diego County, and are therefore Southern Californian province endemics. Fourteen of the Californian endemics are northern species that do not reach Monterey Bay, and may thus be considered endemic to the Northern Californian province.

Subgroup MED-5 (relevés from Pt. Conception and its surroundings), at the border between the Northern Californian and Southern Californian provinces, occupies an intermediate position. Point Conception falls in a region of climatic shift recognized by Thornthwaite [70] and Pickart and Barbour [71]. This shift is reflected in changes in the 
TABLE 5: Summary of differential and common taxa for the boreal (BOR, including the Sitkan and Hudsonian provinces) and Oregonian (ORE) phytogeographical areas. Scores are presence percentages (rounded). Species marked with an asterisk are Oregonian-Californian differential taxa (see Table 6).

\begin{tabular}{|c|c|c|c|c|c|}
\hline & BOR & ORE & & $\mathrm{BOR}$ & ORE \\
\hline Number of sites & 21 & 70 & & 21 & 70 \\
\hline Number of taxa & 110 & 213 & & 110 & 213 \\
\hline $\begin{array}{l}\text { Boreal provinces: } \\
\text { Differential taxa }\end{array}$ & & & $\begin{array}{l}\text { Oregonian province: } \\
\text { Differential taxa }\end{array}$ & & \\
\hline $\begin{array}{l}\text { Betula papyrifera var. } \\
\text { kenaica }\end{array}$ & 87 & - & Polygonum paronychia & - & 17 \\
\hline Puccinellia hultenii & 61 & - & Veronica scutellata & - & 16 \\
\hline Senecio pseudoarnica & 61 & - & $\begin{array}{l}\text { Pteridium aquilinum var. } \\
\text { pubescens }\end{array}$ & - & 16 \\
\hline Equisetum sylvaticum & 56 & - & Maianthemum dilatatum & - & 16 \\
\hline $\begin{array}{l}\text { Ligusticum scoticum subsp. } \\
\text { hultenii }\end{array}$ & 52 & - & Schoenoplectus americanus & - & 14 \\
\hline Poa eminens & 52 & - & Carex pansa & - & 14 \\
\hline Stellaria humifusa & 52 & - & Trifolium wormskjoldii & - & 14 \\
\hline Empetrum nigrum & 48 & - & Tsuga heterophylla & - & 13 \\
\hline Geocaulon lividum & 48 & - & Agrostis pallens & - & 13 \\
\hline $\begin{array}{l}\text { Linnaea borealis subsp. } \\
\text { americana }\end{array}$ & 48 & - & $\begin{array}{l}\text { Vicia nigricans subsp. } \\
\text { gigantea }\end{array}$ & - & 13 \\
\hline Picea glauca & 48 & - & Cuscuta salina & - & 13 \\
\hline $\begin{array}{l}\text { Rosa acicularis subsp. } \\
\text { acicularis }\end{array}$ & 48 & - & Spiranthes romanzoffiana & - & 13 \\
\hline Shepherdia canadensis & 48 & - & $\begin{array}{l}\text { Pseudotsuga menziesii var. } \\
\text { menziesii }\end{array}$ & - & 11 \\
\hline Lathyrus palustris & 43 & - & Thuja plicata & - & 11 \\
\hline Lycopodium annotinum & 43 & - & Grindelia integrifolia & - & 11 \\
\hline Orthilia secunda & 43 & - & Poa confinis & - & 11 \\
\hline Sorbus sitchensis & 43 & - & Lilaeopsis occidentalis & - & 11 \\
\hline Angelica lucida & 30 & - & Lathyrus littoralis & - & 10 \\
\hline $\begin{array}{l}\text { Dendranthema arcticum } \\
\text { subsp. arcticum }\end{array}$ & 26 & - & Baccharis pilularis & - & 8 \\
\hline Poa macrocalyx & 22 & - & $\begin{array}{l}\text { Armeria maritima subsp. } \\
\text { californica }\end{array}$ & - & 7 \\
\hline $\begin{array}{l}\text { Artemisia campestris subsp. } \\
\text { borealis }\end{array}$ & 17 & - & & & \\
\hline Atriplex alaskensis & 17 & - & Common taxa & & \\
\hline Salicornia marítima & 17 & - & Leymus mollis subsp. mollis & 91 & 50 \\
\hline Carex ramenskii & 14 & - & Carex lyngbyei & 87 & 39 \\
\hline $\begin{array}{l}\text { Epilobium ciliatum subsp. } \\
\text { glandulosum }\end{array}$ & 14 & - & $\begin{array}{l}\text { Argentina egedii subsp. } \\
\text { egedii }\end{array}$ & 78 & 50 \\
\hline $\begin{array}{l}\text { Parnassia palustris var. } \\
\text { palustris }\end{array}$ & 14 & - & $\begin{array}{l}\text { Plantago maritima var. } \\
\text { juncoides }\end{array}$ & 70 & 24 \\
\hline Puccinellia nutkaensis & 13 & - & Picea sitchensis & 48 & 69 \\
\hline $\begin{array}{l}\text { Puccinellia phryganodes } \\
\text { subsp. phryganodes }\end{array}$ & 13 & - & $\begin{array}{l}\text { Hordeum brachyantherum } \\
\text { subsp. brachyantherum* }\end{array}$ & 61 & 11 \\
\hline \multirow[t]{2}{*}{$\begin{array}{l}\text { Rhinanthus minor subsp. } \\
\text { groenlandicus }\end{array}$} & 13 & - & $\begin{array}{l}\text { Lathyrus japonicus var. } \\
\text { maritimus }\end{array}$ & 61 & 50 \\
\hline & & & $\begin{array}{l}\text { Honkenya peploides subsp. } \\
\text { major* }\end{array}$ & 56 & 11 \\
\hline
\end{tabular}


Table 5: Continued.

\begin{tabular}{|c|c|c|c|c|c|}
\hline & $\mathrm{BOR}$ & ORE & & $\mathrm{BOR}$ & ORE \\
\hline Number of sites & 21 & 70 & & 21 & 70 \\
\hline Number of taxa & 110 & 213 & & 110 & 213 \\
\hline $\begin{array}{l}\text { Oregonian province: } \\
\text { Differential taxa }\end{array}$ & & & Conioselinum gmelinii & 56 & 3 \\
\hline Gaultheria shallon & - & 60 & Viburnum edule* & 52 & 1 \\
\hline Vaccinium ovatum & - & 50 & Festuca rubra subsp. rubra & 52 & 26 \\
\hline $\begin{array}{l}\text { Lonicera involucrata var. } \\
\text { involucrata }\end{array}$ & - & 43 & Achillea millefolium & 52 & 26 \\
\hline Salix hookeriana & - & 41 & Vaccinium uliginosum* & 48 & 1 \\
\hline Ammophila arenaria & - & 41 & Triglochin maritimum & 48 & 33 \\
\hline Pinus contorta var. contorta & - & 39 & Dryopteris expansa & 48 & 4 \\
\hline Myrica califórnica & - & 37 & Oplopanax horridus* & 43 & 4 \\
\hline Carex obnupta & - & 36 & Menziesia ferruginea* & 43 & 3 \\
\hline Juncus lesueurii & - & 33 & Tiarella trifoliata* & 43 & 3 \\
\hline Polystichum munitum & - & 33 & $\begin{array}{l}\text { Vaccinium } \\
\text { membranaceum* }\end{array}$ & 43 & 3 \\
\hline Hypochaeris radicata & - & 27 & $\begin{array}{l}\text { Athyriumfilix-femina subsp. } \\
\text { cyclosurum }\end{array}$ & 43 & 1 \\
\hline Sarcocornia perennis* & - & 26 & $\begin{array}{l}\text { Deschampsia cespitosa } \\
\text { subsp. beringensis }\end{array}$ & 35 & 37 \\
\hline Juncus falcatus & 一 & 26 & Mertensia maritima* & 35 & 1 \\
\hline Distichlis spicata & 一 & 24 & Calamagrostis canadensis* & 22 & 7 \\
\hline Jaumea carnosa & - & 24 & $\begin{array}{l}\text { Chamerionangustifolium } \\
\text { subsp. circumvagum* }\end{array}$ & 22 & 1 \\
\hline Arctostaphylos uva-ursi & - & 24 & Galium aparine & 22 & 3 \\
\hline Anaphalis margaritacea & - & 23 & $\begin{array}{l}\text { Equisetumtelmateia var. } \\
\text { braunii* }^{*}\end{array}$ & 13 & 8 \\
\hline Cakile maritima & - & 23 & Glaux maritima* & 13 & 20 \\
\hline Cytisus scoparius & - & 23 & Ranunculus cymbalaria* & 13 & 1 \\
\hline Lupinus littoralis & - & 23 & Atriplex patula & 9 & 21 \\
\hline Alnus rubra & - & 20 & $\begin{array}{l}\text { Fragariachiloensis subsp. } \\
\text { pacifica }\end{array}$ & 9 & 34 \\
\hline Tanacetum camphoratum & - & 20 & Juncus balticus & 9 & 17 \\
\hline Cardionema ramosissimum & - & 17 & $\begin{array}{l}\text { Cakile edentula subsp. } \\
\text { edentula var. edentula }\end{array}$ & 4 & 29 \\
\hline
\end{tabular}

flora and coastal vegetation. Apart from some local endemics in the dune systems of Point Conception, many plants of Northern Californian distribution reach their southern limit and coexist for the first time with the taxa of the Southern Californian group. Breckon and Barbour [72], Barbour et al. [73] and Raven et al. [63] assigned the ecotone between two ecofloristic coastal floras to this area. Between Pt. Conception and San Diego, we find the large urban developments of southern California whose dune ecosystems have disappeared completely, although some last century works indicate their floristic relationship with those of Point Conception [74], supporting their inclusion in the Southern Californian phytogeographical province.
Subgroups MED-6 and MED-7 comprise the sites of the southwestern corner of California and those of Baja California north of parallel $30^{\circ} 30^{\prime} \mathrm{N}$, that is, they occupy a semiarid Mediterranean subzone, whose flora is characterized by the so-called Peninsular floristic element, corresponding to the Martirense phytogeographical province [10]. The Mediterranean climate area of northwestern Baja California harbours 41 exclusive taxa, which means that in this small area spanning a little over two degrees of latitude from San Diego to El Rosario, there are 83 Californian endemics, 49\% of which are local endemics. Three monospecific genera are endemic to the area: Cneoridium, Ornitostaphylos, and Xylococcus; and further three, Aphanisma, Bergerocactus, 
TABLE 6: Summary of differential and common taxa of the Californian region (CAL) and the Oregonian province (ORE). See Tables 5 and 7 for further differential taxa of the two zones (species marked with an asterisk in Table 5 are differential taxa of the Oregonian province and those marked in Table 7 are differential taxa of the Californian region). Scores as in Table 5.

\begin{tabular}{|c|c|c|c|c|c|}
\hline & CAL & ORE & & CAL & ORE \\
\hline Number of sites & 94 & 70 & & 94 & 70 \\
\hline Number of taxa & 389 & 213 & & 389 & 213 \\
\hline $\begin{array}{l}\text { Californian province: } \\
\text { Differential taxa }\end{array}$ & & & Common taxa & & \\
\hline $\begin{array}{l}\text { Eriophyllum } \\
\text { stoechadifolium* }\end{array}$ & 31 & - & Ambrosia chamissonis & 40 & 4 \\
\hline Sarcocornia pacifica & 34 & & Cakile maritima & 35 & 23 \\
\hline Carpobrotus chilensis & 30 & - & Baccharis pilularis* & 35 & 9 \\
\hline Erigeron glaucus* & 25 & - & Distichlis spicata & 35 & 24 \\
\hline Artemisia californica* & 24 & - & $\begin{array}{l}\text { Camissonia cheiranthifolia } \\
\text { subsp. cheiranthifolia* }\end{array}$ & 27 & 3 \\
\hline Artemisia pycnocephala* & 20 & - & Abronia latifolia* & 23 & 4 \\
\hline Eriogonum latifolium* & 20 & - & Achillea millefolium* & 29 & 26 \\
\hline $\begin{array}{l}\text { Lotus scoparius var. } \\
\text { scoparius* }\end{array}$ & 20 & - & Jaumea carnosa & 21 & 24 \\
\hline Eriogonum parvifolium* & 17 & - & Ammophila arenaria* & 21 & 41 \\
\hline $\begin{array}{l}\text { Corethrogyne californica } \\
\text { var. californica* }\end{array}$ & 16 & - & Cuscuta salina & 19 & 13 \\
\hline Agave shawii subsp. shawii & 16 & - & $\begin{array}{l}\text { Armeria maritima subsp. } \\
\text { californica* }\end{array}$ & 15 & 7 \\
\hline Bergerocactus emoryi & 16 & - & $\begin{array}{l}\text { Rubus ursinus subsp. } \\
\text { ursinus* }\end{array}$ & 14 & 3 \\
\hline Rhus integrifolia & 15 & - & Calystegia soldanella* & 13 & 7 \\
\hline Ericameria ericoides* & 15 & - & Polygonum paronychia* & 12 & 17 \\
\hline $\begin{array}{l}\text { Eriogonum fasciculatum var. } \\
\text { fasciculatum }\end{array}$ & 14 & - & Leymus mollis subsp. mollis & 12 & 50 \\
\hline Nassella lepida* & 14 & - & Lupinus arboreus* & 11 & 3 \\
\hline Eschscholzia californica & 13 & - & $\begin{array}{l}\text { Argentina egedii subsp. } \\
\text { egedii* }\end{array}$ & 8 & 50 \\
\hline Salix lasiolepis* & 13 & - & Lathyrus littoralis & 5 & 10 \\
\hline Amblyopappus pusillus & 13 & - & $\begin{array}{l}\text { Pseudotsuga menziesii var. } \\
\text { menziesii }\end{array}$ & 3 & 11 \\
\hline $\begin{array}{l}\text { Encelia californica var. } \\
\text { californica }\end{array}$ & 11 & - & Picea sitchensis & 3 & 69 \\
\hline Mirabilis califórnica & 11 & - & Gaultheria shallon & 3 & 60 \\
\hline Dudleya cultrata & 10 & - & Vaccinium ovatum & 1 & 50 \\
\hline $\begin{array}{l}\text { Oregonian province: } \\
\text { Differential taxa }\end{array}$ & & & $\begin{array}{l}\text { Lathyrus japonicus var. } \\
\text { maritimus }\end{array}$ & 1 & 50 \\
\hline Carex lyngbyei & - & 39 & Salix hookeriana & 3 & 41 \\
\hline $\begin{array}{l}\text { Deschampsia cespitosa } \\
\text { subsp. beringensis }\end{array}$ & - & 37 & Pinus contorta var. contorta & 2 & 39 \\
\hline $\begin{array}{l}\text { Cakile edentula subsp. } \\
\text { edentula var. edentula }\end{array}$ & - & 29 & Myrica californica & 8 & 37 \\
\hline Sarcocornia perennis & - & 26 & Carex obnupta & 6 & 36 \\
\hline Arctostaphylos uva-ursi & - & 24 & Triglochin maritimum & 8 & 33 \\
\hline $\begin{array}{l}\text { Plantago maritima var. } \\
\text { juncoides }\end{array}$ & - & 24 & Atriplex patula & 8 & 21 \\
\hline
\end{tabular}


TABle 6: Continued.

\begin{tabular}{|c|c|c|c|c|c|}
\hline & CAL & ORE & & CAL & ORE \\
\hline Number of sites & 94 & 70 & & 94 & 70 \\
\hline Number of taxa & 389 & 213 & & 389 & 213 \\
\hline $\begin{array}{l}\text { Californian province: } \\
\text { Differential taxa }\end{array}$ & & & Common taxa & & \\
\hline Cytisus scoparius & - & 23 & $\begin{array}{l}\text { Fragaria chiloensis subsp. } \\
\text { pacifica* }\end{array}$ & 15 & 34 \\
\hline Lupinus littoralis & - & 23 & Juncus lesueurii* & 14 & 33 \\
\hline Glaux maritima & - & 20 & Polystichum munitum & 5 & 33 \\
\hline Veronica scutellata & - & 16 & Hypochaeris radicata & 2 & 27 \\
\hline Trifolium wormskjoldii & - & 14 & Festuca rubra subsp. rubra & 1 & 26 \\
\hline Tsuga heterophylla & - & 13 & Juncus falcatus & 4 & 26 \\
\hline Agrostis pallens & - & 13 & Anaphalis margaritacea & 1 & 23 \\
\hline $\begin{array}{l}\text { Vicia nigricans subsp. } \\
\text { gigantea }\end{array}$ & - & 13 & Alnus rubra & 3 & 20 \\
\hline Spiranthes romanzoffiana & - & 13 & Tanacetum camphoratum & 3 & 20 \\
\hline Thuja plicata & - & 11 & Juncus balticus & 3 & 17 \\
\hline Grindelia integrifolia & - & 11 & Cardionema ramosissimum & 4 & 17 \\
\hline Poa confinis & - & 11 & $\begin{array}{l}\text { Pteridium aquilinum var. } \\
\text { pubescens }\end{array}$ & 4 & 16 \\
\hline Lilaeopsis occidentalis & - & 11 & Maianthemum dilatatum & 2 & 16 \\
\hline
\end{tabular}

and Harfordia, are almost endemic. Of the 12 Californian endemic genera, ten (except for Ericameria and Sequoia) are also present in northwestern Baja California.

Subgroup ZEC-2 included 14 sites at $29^{\circ}$ to $30^{\circ} 30^{\prime} \mathrm{N}$, in the transition area between the Mediterranean and tropical zones. The flora in cluster ZEC-2 shows features that are intermediate between those of the climatic zones Mediterranean and tropical, but the climatic characteristics of this zonoecotone are Mediterranean, and the proportion of infra-generic taxa related to the Mediterranean zone is much higher than that related to the tropical zone in its entirety (Table 4). Peinado et al. [19] examined the flora of this territory and included it in the Martirense province.

\subsubsection{Tropical Climate Area (ZONOBIOME III): Baja Cali-} fornian and Sanlucan Provinces. The flora of Baja California, except in its northwestern corner belonging to the Martirense province, is characterised by a high number of taxa related to tropical flora, especially to those with which links with South America may be established. Only $4 \%$ of the species of the tropical zone belong to elements of wide distribution. This zone completely lacks species of Holarctic and cosmopolitan distribution. In contrast, taxa related to the tropical element, Sonoran endemics and Baja Californian endemics, represent $39.6 \%$ of the genera and $69.3 \%$ of species. Two provinces are distinguished in the tropical zone: Baja Californian and Sanlucan. Besides their differentiation by vegetation types specific to each [19], both provinces can be floristically distinguished. In the Baja Californian province, we find plants of Southern Mediterranean-Tropical distribution that are completely lacking in the Sanlucan province. Tables 3 and 4 reveal a clear floristic separation between subgroup
TRO-1 and the remaining three tropical subgroups. The taxa differentiating subgroup TRO-1 with respect to the subgroups TRO- 3 and TRO- 4 are characteristic elements of the Baja Californian floristic province. The southernmost subgroups TRO-3 and TRO-4 show a set of taxa that are endemic to the Sanlucan province or whose distribution area in Baja California is restricted to this province. The Sanlucan province has long been known to be an important area of biogeographical differentiation, whose floristic catalogue contains 1053 vascular plants, 293 of which are peninsular endemics, including 132 local endemics [10]. The history of geological isolation of the Sanlucan province as an island, since its formation in the late Jurassic-early Cretaceous up until Plio-Pleistocene times [75] could help explain the original nature of this province.

\section{Conclusions}

(1) There are eight phytogeographical provinces along the coast of the North American Pacific: Hudsonian, Sitkan, Oregonian, Northern Californian, Southern Californian, Martirense, Bajacalifornian, and Sanlucan, characterized in our cluster analysis by floristic differences. According to our analysis of vascular flora, floristic differences among provinces are related to palaeoclimatic and palaeogeographical events. The flora of the area examined includes endemic elements as well as elements of wider distribution, allowing us to establish relationships with the floras of Eurasia, Africa and South America.

(2) The northern provinces Hudsonian, Sitkan, and Oregonian present high percentages of broadly distributed elements, whose origins can be found in the Boreotropical or Arcto-Tertiary geoflora that dominated the Northern 
TABle 7: Summary of differential and common taxa of the Californian (CAL, including the Northern,Southern and Martirense provinces) and tropical (TRO, including the Bajacalifornian and Sanlucan provinces) phytogeographical zones. Further differential taxa of the two zones can be found in Table 6 (species marked with an asterisk in Table 6 are Californian differential taxa). Scores as in Table 5.

\begin{tabular}{|c|c|c|c|c|c|}
\hline & TRO & CAL & & TRO & $\overline{\mathrm{CAL}}$ \\
\hline Number of sites & 91 & 94 & & 91 & 94 \\
\hline Number of taxa & 240 & 389 & & 240 & 389 \\
\hline $\begin{array}{l}\text { Tropical provinces: } \\
\text { Differential taxa }\end{array}$ & & & Common taxa & & \\
\hline Cenchrus palmeri & 64 & - & Allenrolfea occidentalis * & 50 & 1 \\
\hline Maytenus phyllantoides & 49 & - & Abronia maritima* & 35 & 16 \\
\hline Jouvea pilosa & 29 & - & Frankenia palmeri* & 33 & 6 \\
\hline Sporobolus virginicus & 29 & - & Batis maritima* & 32 & 11 \\
\hline Euphorbia leucophylla & 27 & - & Atriplex julacea* & 30 & 10 \\
\hline Proboscidea althaefolia & 25 & - & Monanthochloe littoralis & 27 & 15 \\
\hline Cyrtocarpa edulis & 22 & - & Camissonia crassifolia & 22 & 4 \\
\hline Ipomoea pes-caprae & 22 & - & Lycium californicum* & 19 & 15 \\
\hline Rhizophora mangle & 22 & - & Euphorbia misera* & 19 & 16 \\
\hline $\begin{array}{l}\text { Oenothera drummondii var. } \\
\text { thalassaphila }\end{array}$ & 20 & - & $\begin{array}{l}\text { Arthrocnemum } \\
\text { subterminale* }^{*}\end{array}$ & 19 & 13 \\
\hline Fouquieria diguetii & 20 & - & Sarcocornia pacifica & 19 & 34 \\
\hline Avicennia germinans & 20 & - & Lycium brevipes* & 18 & 15 \\
\hline Laguncularia racemosa & 20 & - & Suaeda taxifolia* & 16 & 4 \\
\hline $\begin{array}{l}\text { Phaseolusacutifolius var. } \\
\text { latifolius }\end{array}$ & 20 & - & Croton californicus & 16 & 6 \\
\hline $\begin{array}{l}\text { Lycium fremontii var. } \\
\text { congestum }\end{array}$ & 19 & - & Stenocereus gummosus & 15 & 12 \\
\hline Opuntia cholla & 19 & - & $\begin{array}{l}\text { Mesembryanthemum } \\
\text { crystallinum* }\end{array}$ & 15 & 16 \\
\hline Encelia ventorum & 18 & - & $\begin{array}{l}\text { Atriplexcanescens var. } \\
\text { canescens }\end{array}$ & 14 & 8 \\
\hline Froelichia interrupta & 18 & - & Suaeda moquinii & 14 & 4 \\
\hline $\begin{array}{l}\text { Dalea divaricata subsp. } \\
\text { anthonyi }\end{array}$ & 16 & - & Lycium andersonii & 12 & 5 \\
\hline Asclepias subulata & 15 & - & Spartina foliosa* & 12 & 28 \\
\hline Atriplex magdalenae & 15 & - & Abronia umbellata & 10 & 10 \\
\hline Porophyllum maritimum & 15 & - & $\begin{array}{l}\text { Atriplexbarclayana subsp. } \\
\text { barclayana }\end{array}$ & 9 & 1 \\
\hline Jatropha cinérea & 14 & - & Suaeda esteroa* & 7 & 14 \\
\hline Antigonon leptopus & 13 & 一 & Frankenia salina* & 5 & 27 \\
\hline Portulaca pilosa & 13 & - & Ambrosia dumosa & 5 & 1 \\
\hline Euphorbia micromera & 13 & - & Sarcostemma arenarium & 5 & 2 \\
\hline Condaliopsis rigida & 13 & - & $\begin{array}{l}\text { Cryptanthamaritima var. } \\
\text { maritima }\end{array}$ & 5 & 3 \\
\hline Jatropha cuneata & 12 & - & Stillingia linearifolia & 4 & 1 \\
\hline Bursera microphylla & 12 & - & Atriplex leucophylla* & 4 & 14 \\
\hline Chaenactis lacera & 10 & - & Distichlis spicata & 4 & 24 \\
\hline Pachycereus pringlei & 10 & - & $\begin{array}{l}\text { Helianthus niveus subsp. } \\
\text { niveus }\end{array}$ & 4 & 13 \\
\hline Jatropha cordata & 10 & - & $\begin{array}{l}\text { Isocomamenziesii var. } \\
\text { vernonioides }\end{array}$ & 3 & 8 \\
\hline Castela peninsularis & 10 & - & Limonium californicum & 3 & 19 \\
\hline
\end{tabular}


TABle 7: Continued.

\begin{tabular}{|c|c|c|c|c|c|}
\hline & TRO & CAL & & TRO & CAL \\
\hline Number of sites & 91 & 94 & & 91 & 94 \\
\hline Number of taxa & 240 & 389 & & 240 & 389 \\
\hline $\begin{array}{l}\text { Tropical provinces: } \\
\text { Differential taxa }\end{array}$ & & & Common taxa & & \\
\hline $\begin{array}{l}\text { Drymaria holosteoides var. } \\
\text { crassifolia }\end{array}$ & 9 & - & Dudleya cultrata & 2 & 10 \\
\hline Physalis glabra & 9 & - & Mirabilis californica & 2 & 11 \\
\hline Achyronychia cooperi & 8 & - & Salicornia bigelovii & 2 & 10 \\
\hline $\begin{array}{l}\text { Encelia farinosa var. } \\
\text { Phenocodonta }\end{array}$ & 8 & - & $\begin{array}{l}\text { Camissoniacheiranthifolia } \\
\text { subsp. suffruticosa }\end{array}$ & 1 & 7 \\
\hline Sphaeralcea fulva & 8 & - & Cuscuta salina & 1 & 19 \\
\hline Trianthema portulacastrum & 8 & - & Echinocereus maritimus & 1 & 11 \\
\hline Atriplex polycarpa & 7 & - & Lepidium nitidum & 1 & 4 \\
\hline Dyssodia anthemidifolia & 7 & - & Rhus integrifolia & 1 & 15 \\
\hline Perityle emoryi & 7 & - & Ribes speciosum & 1 & 6 \\
\hline Coulterella capitata & 7 & - & Rosa minutifolia & 1 & 7 \\
\hline Dalea tinctoria var. tinctoria & 7 & - & $\begin{array}{l}\text { Pentagrammatriangularis } \\
\text { var. viscosa }\end{array}$ & 1 & 5 \\
\hline $\begin{array}{l}\text { Hofmeisteria fasciculata var. } \\
\text { fasciculata }\end{array}$ & 7 & - & Malosma laurina & 1 & 8 \\
\hline Triteleiopsis palmeri & 7 & - & Isomeris arborea & 1 & 3 \\
\hline
\end{tabular}

Hemisphere during the Tertiary. The temperate and boreal macroclimates that characterize these northern areas are widespread at the continental and intercontinental level, allowing the intense exchange of species. Accordingly, these provinces show very low proportions of local endemics and exclusive species. The influence of the glaciations of the Pleistocene is also appreciable in boreal and temperate areas although the lack of effects of glaciations in Alaska-Yukon has led to the survival of some Hudsonian endemics.

(3) The floristically richest provinces in terms of their high number of endemic taxa are the three that occupy the Mediterranean zone, since these provinces harbour elements of the Arcto-Tertiary and Madro-Tertiary geofloras. Moreover, the Mediterranean coast acted as a refuge sheltering plants from the climatic events of the Late Tertiary and Quaternary that decimated the flora of the more northern provinces.

(4) The boreal zone has the highest percentage of widely distributed elements (Cosmopolitan, Holarctic, North American, and Western North American), which together represent $63.6 \%$ of the species and $79.6 \%$ of genera. It is also the group with the greatest proportions of genera and species showing a North American-Eastern Asian distribution, which seems to be attributable to the persistence of the Bering Land bridge up until 10.000 years ago. Close to $12 \%$ of its species are endemic. This can be linked to the lack of glaciations in Central Yukon during fullglacial periods.
(5) Within the boreal zone, we can distinguish two phytogeographical provinces: Hudsonian and Sitkan. The first province, widely extended across the boreal climate zone of North America, only reaches as far as the Pacific coast at Cook Inlet, Alaska. The Hudsonian climax forests dominated by Picea glauca constitute the main difference between this province and the Sitkan province, whose coastal forests are dominated by Picea sitchensis.

(6) The temperate climate zone is the second in importance in terms of its proportions of wide-distribution elements, which account for $49.9 \%$ of the species and $42.1 \%$ of genera. Only two species are endemic to this zone because of the broad expansion of the temperate climate across North America, which has allowed the substantial interchange of taxa on the continental scale. Hence, the temperate group is the one showing the highest proportions of taxa belonging to the subelements North American and Western North American. No significant floristic differences were detected in the temperate climate zone, which may be considered as a single province, indisputably denoted the Oregonian province. Between the Oregonian and the Northern Californian provinces there is a large transition zone, and the limits of the two provinces have been ascribed different latitudes. Our floristic analyses locate this boundary at around $42^{\circ} \mathrm{N}$, coinciding with substantial changes in the flora and coastal vegetation.

(7) Only $21.5 \%$ of the species of the Mediterranean climate zone belong to the elements of wide distribution that 
TABLE 8: Main floristical differences among Californian provinces. Only coastal taxa are shown.

\begin{tabular}{|c|c|c|}
\hline Northern Californian province endemics & Southern Californian province endemics & Martirense province endemics \\
\hline Agrostis blasdalei & Arctostaphylos cruzensis & Achnatherum diegoensis \\
\hline Arabis blepharophylla & Arctostaphylos edmundsii & Aesculus parryi \\
\hline Castilleja wightii & Arctostaphylos hookeri subsp. hearstiorum & Agave shawii subsp. shawii \\
\hline Erysimum menziesii subsp. concinnum & Arctostaphylos morroensis & Astragalus anemophilus \\
\hline Erysimum menziesii subsp. eurekense & Arctostaphylos rudis & Astragalus harbisonii \\
\hline Grindelia hirsutula var. hirsutula & Arctostaphylos pumila & Bergerocactus emoryi \\
\hline Grindelia stricta subsp. platyphylla & Castilleja mollis & Ceanothus verrucosus \\
\hline Heterotheca sessiliflora subsp. bolanderi & Ceanothusmegacarpus var. megacarpus & Chamaebatia australis \\
\hline Lotus junceus var. biolettii & Chorizanthe pungens & Cneoridium dumosum \\
\hline Lupinus variicolor & Cirsium loncholepis & Dudleyaattenuata subsp. orcuttii \\
\hline Phacelia argéntea & Dudleya caespitosa & Dudleya campanulata \\
\hline Sequoia sempervirens & Erigeron blochmaniae & Dudleya cultrata \\
\hline Solidago spathulata subsp. spathulata & Erysimuminsulare subsp. suffrutescens & Dudleya ingens \\
\hline Stellaria littoralis & Erysimummenziesii subsp. yadonii & Echinocereus maritimus \\
\hline \multicolumn{3}{|l|}{ Malacothrix incana } \\
\hline Angelica lucida & Monardella crispa & Haplopappus berberidis \\
\hline Armeria maritima subsp. californica & Differential taxa of the southern provinces & Haplopappus rosaricus \\
\hline Carex lyngbyei & Amblyopappus pusillus & Haplopappusvenetus subsp. tridentatus \\
\hline Castilleja ambigua subsp. ambigua & Aphanisma blitoides & Malacothamnus densiflorus \\
\hline Conioselinum gmelinii & Atriplex watsonii & Mammillaria brandegei \\
\hline Disporum smithii & Camissoniacheiranthifolia subsp. suffruticosa & Opuntia littoralis \\
\hline Glehnia littoralis subsp. leiocarpa & Coreopsis maritima & Opuntia rosarica \\
\hline Helenium bolanderi & Eriogonum parvifolium & Ornitostaphylos oppositifolia \\
\hline Lathyrus japonicus var. maritimus & Isocoma menziesii var. sedoides & Pinus torreyana \\
\hline Picea sitchensis & Malacothamnus fasciculatus & Ribes tortuosum \\
\hline Pinus contorta var. contorta & Opuntia prolifera & Rosa minutifolia \\
\hline Poa confinis & Pentagrammatriangularis var. viscosa & Salvia munzii \\
\hline Poa macrantha & Quercus dumosa & Selaginella cinerascens \\
\hline Salix hookeriana & Suaeda esteroa & Xylococcus bicolor \\
\hline
\end{tabular}

predominate in the boreal and temperate floras. In contrast, it is the zone with the highest concentrations of endemic genera and species, such that it bears a close relationship with the dual origin of its flora and with the climatic isolation of the Mediterranean zone in North America.

(8) Phytogeographically, the entire Mediterranean climate zone could be included in the Californian region, in which three provinces can be discerned: Northern Californian, Southern Californian, and Martirense. These provinces are clearly differentiated by differences in their floristic elements, and by the presence in each of endemic species. The Mediterranean climate zone of northwestern Baja California (Martirense province) has the highest concentration of endemic species. Three genera (Cneoridium, Ornitostaphylos, and Xylococcus) are exclusive endemisms and a further three (Aphanisma, Bergerocactus, and Harfordia) are nearly endemic.

(9) The flora of Baja California, except in its northwestern corner, is characterised by a high number of taxa related to tropical flora, especially to those with which links with South America may be established. Only 3.9\% of the species of the tropical zone belong to elements of wide distribution. In this zone, species of Holarctic and cosmopolitan distribution are totally lacking. In contrast, taxa related to the tropical element, Sonoran endemics and Baja Californian endemics, represent $40 \%$ of the genera and $70 \%$ of species.

(10) Two provinces are distinguished in the tropical zone: Baja Californian and Sanlucan. Besides their differentiation by vegetation types specific to each, both provinces can be floristically distinguished. In the Baja Californian province, we find plants of Southern Mediterranean-Tropical distribution, completely lacking in the Sanlucan province. This latter province also sustains a high number of endemic taxa, including the endemic genus Coulterella.

\section{Appendix}

\section{A. Phytogeographical Elements (Abbreviations as in Table 1)}

A.1. Genera. Abies (HOL), Abronia (WES), Abutilon (PAN), Acacia (PAN), Acalipha (PAN), Acer (HOL), Achillea (HOL), Achnatherum (COS), Achyronychia (SON), 
Acourtia (WES), Adenocaulon (DIS), Adenostoma (CAL), Aeschynomene (PAN), Aesculus (HOL), Agave (NEO), Ageratina (NAS), Agoseris (NAS), Agrostis (COS), Aira (INT), Allenrolfea (MAD), Allium (HOL), Alnus (HOL), Amaranthus (COS), Amblyopappus (NAS), Ambrosia (COS), Ammophila (INT), Anagallis (INT), Anaphalis (HOL), Angelica (DIS), Antigonon (NEO), Antirrhinum (DIS), Aphanisma (CAL), Arbutus (DIS), Arctostaphylos (HOL), Argentina (NAS), Armeria (DIS), Artemisia (HOL), Arthrocnemum (DIS), Asclepias (AAT), Astragalus (HOL), Athyrium (COS), Atriplex (COS), Avicennia (PAN), Baccharis (NAS), Bassia (COS), Batis (APT), Bergerocactus (CAL), Betula (HOL), Blechnum (COS), Brickellia (NAS), Briza (INT), Bromus (COS), Bursera (NEO), Caesalpinia (PAN), Cakile (HOL), Calamagrostis (HOL), Calliandra (PAN), Calochortus (WES), Calystegia (COS), Camissonia (NAS), Cardionema (NAS), Cardiospermum (PAN), Carex (COS), Carpobrotus (INT), Castela (NEO), Castilleja (NAE), Ceanothus (NOA), Cenchrus (PAN), Centaurium (INT), Cerastium (COS), Cercocarpus (MAD), Chaenactis (WES), Chamaebatia (CAL), Chamerion (CAL), Chorizanthe (NAS), Cirsium (HOL), Claytonia (NAE), Clematis (COS), Clintonia (NAE), Cneoridium (CAL), Comarum (HOL), Commelina (PAN), Condalia (NAS), Condaliopsis (NAS), Conicosia (INT), Conioselinum (HOL), Conium (INT), Corallorhiza (HOL), Cordylanthus (WES), Coreocarpus (SON), Coreopsis (DIS), Corethrogyne (WES), Cornus (HOL), Cotula (INT), Coulterella (BAJ), Crassula (COS), Cressa (COS), Croton (PAN), Cryptantha (WES), Cupressus (HOL), Cuscuta (COS), Cynanchum (DIS), Cyrtocarpa (NEO), Cytisus (INT), Dalea (NAS), Dendranthema (HOL), Deschampsia (COS), Dichelostemma (WES), Disporum (NAE), Distichlis (DIS), Ditaxis (NEO), Dithyrea (MAD), Dodecatheon (NAE), Drymaria (NAS), Dryopteris (COS), Dudleya (MAD), Dyssodia (NAS), Echinocereus (MAD), Echinopepon (NAS), Eleocharis (COS), Empetrum (DIS), Encelia (NAS), Ephedra (COS), Epilobium (CAL), Epilobium (COS), Equisetum (COS), Eragrostis (COS), Erechtites (INT), Ericameria (WES), Erigeron (COS), Eriodictyon (MAD), Eriogonum (NOA), Eriophyllum (WES), Errazurizia (NAS), Erysimum (HOL), Eschscholzia (WES), Euphorbia (COS), Fagonia (PAN), Ferocactus (MAD), Festuca (COS), Filago (HOL), Foeniculum (INT), Fouquieria (SON), Fragaria (HOL), Frankenia (DIS), Fraxinus (HOL), Fritillaria (HOL), Froelichia (NEO), Galium (COS), Gaultheria (DIS), Geocaulon (NOA), Geranium (COS), Glaux (HOL), Glehnia (NAE), Gnaphalium (COS), Goodyera (COS), Grindelia (NAS), Haplopappus (NAS), Harfordia (BAJ), Hazardia (WES), Hedera (INT), Helenium (NAS), Helianthus (NOA), Heliotropium (COS), Hemizonia (NOA), Heracleum (HOL), Heteromeles (CAL), Heterotheca (NAS), Heuchera (NOA), Hieracium (HOL), Hierochloe (COS), Hippuris (HOL), Hofmeisteria (NEO), Holcus (INT), Holodiscus. (NAS), Honkenya (DIS), Hordeum (COS), Horsfordia (WES), Houstonia (PAN), Hymenoclea (WES), Hypericum (COS), Hypochaeris (INT), Hyptis (NEO), Ibervillea (WES), Ipomoea (NEO), Iris (HOL), Isocoma (MAD), Isolepis (COS), Isomeris (MAD), Jathropha (AAT), Jaumea (NAS), Jouvea (NAS), Juglans (HOL), Juncus (COS), Justicia (PAN), Keckiella
(CAL), Krameria (NAS), Laguncularia (AAT), Larrea (NAS), Lathyrus (HOL), Leontondon (INT), Lepidium (COS), Leymus (HOL), Ligusticum (HOL), Lilaeopsis (DIS), Limonium (DIS), Linnaea (HOL), Listera (HOL), Lithocarpus (NAE), Lomatogonium (HOL), Lonicera (HOL), Lotus (HOL), Lupinus (DIS), Luzula (COS), Lycium (COS), Lycopodium (COS), Lysichiton (NAE), Maba (PAN), Madia (NAS), Maianthemum (HOL), Malacothamnus (NAS), Malacothrix (WES), Malosma (CAL), Malus (HOL), Malvastrum (MAD), Mammillaria (NAS), Marah (WES), Maytenus (PAN), Melica (COS), Melilotus (INT), Mentha (COS), Menziesia (NAE), Mertensia (HOL), Mesembryanthemum (INT), Mimulus (DIS), Mirabilis (NAE), Momordica (PAN), Monanthochloe (NAS), Monardella (WES), Myosurus (DIS), Myrica (COS), Myrtillocactus (NEO), Nassella. (NAS), Nemacaulis (MAD), Nicotiana (DIS), Nolina (MAD), Oenanthe (COS), Oenothera (NAS), Oligomeris (DIS), Olneya (SON), Oplopanax (NAE), Opuntia (NAS), Ornitostaphylos (CAL), Orthilia (HOL), Osmorhiza (NAE), Oxalis (COS), Pachycereus (SON), Pachycormus (BAJ), Palafoxia (SON), Parentucellia (INT), Parkinsonia (SON), Parnassia (HOL), Passiflora (APT), Pedilanthus (NEO), Pentagramma (WES), Perityle (MAD), Peucephyllum (SON), Phacelia (NAS), Phaseolus (NEO), Phoradendron (NAS), Phrygilanthus (NEO), Physalis (COS), Picea (HOL), Pinus (DIS), Pithecellobium (PAN), Plantago (COS), Pleuraphis (NAS), Poa (COS), Polycarpon (COS), Polygonum (HOL), Polypodium (COS), Polypogon (INT), Polystichum (COS), Populus (HOL), Porophyllum (NAS), Portulaca (COS), Potentilla (HOL), Proboscidea (NAS), Prosopis (PAN), Prunus (COS), Pseudotsuga (NAE), Pteridium (COS), Puccinellia (HOL), Pyrola (HOL), Quercus (HOL), Ranunculus (COS), Raphanus (INT), Rhamnus (HOL), Rhinanthus (HOL), Rhizophora (PAN), Rhododendron (COS), Rhus (COS), Ribes (DIS), Rorippa (COS), Rosa (HOL), Rubus (COS), Rumex (COS), Sagina (COS), Salicornia (COS), Salix (HOL), Salsola (DIS), Salvia (COS), Sambucus (COS), Sanicula (COS), Sapindus (APT), Sarcocornia. (DIS), Sarcostemma (PAN), Saussurea (DIS), Scaevola (PAN), Schismus (INT), Schoenoplectus (COS), Scrophularia (HOL), Selaginella (COS), Senecio (COS), Sequoia (CAL), Sesuvium (COS), Setaria (COS), Shepherdia (NOA), Silene (HOL), Simmondsia (MAD), Sisyrinchium (NAS), Solanum (COS), Solidago (HOL), Sonchus (INT), Sorbus (HOL), Spartina (HOL), Spergularia (DIS), Sphaeralcea (AAT), Spiraea (HOL), Spiranthes (COS), Sporobolus (COS), Stachys (COS), Stegnosperma (MAD), Stellaria (COS), Stenocereus (NEO), Stephanomeria (WES), Stillingia (PAN), Suaeda (DIS), Symphyotrichum (NOA), Tamarix (INT), Tanacetum (HOL), Tetragonia (INT), Thuja (NAE), Tiarella (NAE), Tillaea (COS), Tiquilia (NEO), Toxicodendron (NAE), Trianthema (PAN), Trientalis (HOL), Trifolium (COS), Triglochin (DIS), Triphysaria (WES), Triteleiopsis (SON), Trixis (NAS), Tsuga (NAE), Typha (COS), Ulex (INT), Umbellularia (CAL), Urtica (COS), Vaccinium (HOL), Vallesia (NEO), Veronica (COS), Viburnum (COS), Vicia (HOL), Viguiera (NAS), Viola (DIS), Viscainoa (BAJ), Vulpia (INT), Washingtonia (WES), Wislizenia (WES), Xerophyllum (NOA), Xylococcus (CAL), and Yucca (MAD). 
A.2. Infrageneric Taxa. Abies grandis var. grandis (WES), Abronia latifolia (PAC), A. maritima (MAD), A.umbellata subsp. umbellata (MAD), Abutilon carterae (BAJ), Acacia peninsularis (BAJ), Acalypha californica (MAD), Acer glabrum (NOA), A. macrophyllum (WES), Achillea millefolium (HOL), Achnatherum diegoenis (CAL), Achyronychia cooperi (SON), Acourtia microcephala (CAL), Adenocaulon bicolor (NOA), Adenostoma fasciculatum (CAL), Aeschynomene nivea (BAJ), Aesculus parryi (BAJ), Agave datylio var. vexans (BAJ), A. shawii subsp. sebastiana (BAJ), A. shawii subsp. shawii (CAL), Ageratina adenophora (INT), Agoseris apargioides var. eastwoodieae (PAC), Agrostis blasdalei (CAL), A. exarata (NOA), A. pallens (WES), A. stolonifera (COS), Aira cariophyllea (INT), Allenrolfea occidentalis (MAD), Allium haematochiton (MAD), Alnus rubra (WES), Amaranthus watsonii (SON), Amblyopappus pusillus (CAL), A. ambrosioides (SON), A. chamissonis (NAS), A. chenopodifolia (MAD), A. dumosa (SON), Ammophila arenaria (INT), Anagallis arvensis (INT), Anaphalis margaritacea (HOL), Angelica genuflexa (PAC), A. hendersonii (PAC), A. lucida (NAE), Antigonon leptopus (SON), Antirrhinum cyathiferum (SON), A. nuttallianum subsp. subsessile (MAD), Aphanisma blitoides (CAL), Arabis blepharophylla (CAL), Arbutus menziesii (PAC), Arctostaphylos columbiana (PAC), A. cruzensis (CAL), A. edmundsii (CAL), A. hookeri subsp. hearstiorum (CAL), A. morroensis (CAL), A. pumila (CAL), A. rudis (CAL), A. uva-ursi (HOL), Argentina egedii subsp. egedii (NAE), Armeria maritima subsp. californica (PAC), Artemisia californica (CAL), A. campestris subsp. borealis (HOL), A. pycnocephala (CAL), Arthrocnemum subterminale (MAD), Asclepias albicans (SON), A. subulata (SON), Astragalus anemophilus (BAJ), A. fastidius (BAJ), A. harbisonii (BAJ), A. magdalenae var. magdalenae (SON), A. nuttallianus var. cedrodensis (SON), A. nuttallii (CAL), A. trichopodus (CAL), Athyrium filix-femina subsp. cyclosurum (NOA), Atriplex alaskensis (BOR), A. barclayana subsp. barclayana (SON), A. barclayana subsp. sonorae (SON), A. canescens subsp. canescens (NOA), A. canescens subsp. linearis ( $\mathrm{SON}$ ), A. drymarioides (BOR), A. hymenelytra (SON), A. julacea (BAJ), A. leucophylla (CAL), A. magdalenae (BAJ), A. patula (INT), A. polycarpa (NOA), A. semibaccata (INT), A. watsonii (CAL), Avicennia germinans (NEO), Baccharis douglasii (CAL), B. pilularis (CAL), B. sarothroides (MAD), Bassia hyssopifolia (INT), Batis maritima (NAS), Bergerocactus emoryi (CAL), Betula papyrifera var. kenaica (BOR), Blechnum spicant (HOL), Brickellia californica (CAL), Briza maxima (INT), Bromus carinatus (WES), B. diandrus (INT), B. madritensis (INT), B. vulgaris (WES), Bursera cerasifolia (BAJ), B. epinnata (BAJ), B. filicifolia (BAJ), B. hindsiana (SON), B. microphylla (SON), B. odorata (SON), Caesalpinia placida (BAJ), Cakile edentula subsp. edentula var. edentula (NOA), C. maritima (INT), Calamagrostis canadensis (NOA), Calliandra eriophylla (SON), Calochortus concolor (CAL), Calystegia macrostegia subsp. cyclostegia (CAL), C. macrostegia subsp. tenuifolia (CAL), C. occidentalis (CAL), C. sepium subsp. angulata (NOA), C. soldanella (COS), Camissonia cardiophylla subsp. cedrosensis (BAJ), C. cheiranthifolia subsp. cheiranthifolia (CAL), C. cheiranthifolia subsp. suffruticosa (CAL), C. crassifolia (BAJ), Cardionema ramosissimum (NAS), Cardiospermum corindum (NEO), Carex aquatilis var. dives (WES), C. cusickii (WES), C. lenticularis var. limnophila (WES), C. lenticularis var. lipocarpa (WES), C. lyngbyei (HOL), C. macrocephala (NAE), C. mertensii (WES), C. obnupta (PAC), C. pansa (PAC), C. pluriflora (PAC), C. ramenskii (NAE), Carpobrotus chilensis (INT), C. edulis (INT), Castela peninsularis (BAJ), Castilleja affinis subsp. affinis (CAL), C. ambigua subsp. ambigua (PAC), C. foliolosa (CAL), C. latifolia (CAL), C. mollis (CAL), C. unalaschcensis (BOR), C. wightii (CAL), Ceanothus cuneatus var. cuneatus (CAL), C. megacarpus (CAL), C. sorediatus (CAL), C. thyrsiflorus (CAL), C. verrucosus (CAL), Cenchrus palmeri (SON), Centaurium erythraea (INT), Cerastium fontanum subsp. vulgare (INT), Cercocarpus betuloides var. betuloides (CAL), Chaenactis lacera (BAJ), Chamaebatia australis (CAL), Chamerion angustifolium subsp . circumvagum (HOL), Chorizanthe pungens (CAL), Cirsium arvense (INT), C. loncholepis (CAL), Claytonia perfoliata subsp. mexicana (NAS), C. sibirica var. sibirica (WES), Clematis lasiantha (CAL), Clintonia uniflora (WES), Cneoridium dumosum (CAL), Comarum palustre (HOL), Commelina diffusa (NOA), Condalia globosa (SON), Condaliopsis rigida (BAJ), Conicosia pugioniformis (INT), Conioselinum gmelinii (NAE), Conium maculatum (INT), Corallorhiza mertensiana (WES), Cordylanthus maritimus (CAL), Coreocarpus parthenoides var. parthenoides (SON), Coreopsis maritima (CAL), Corethrogyne californica var. californica (CAL), Cornus canadensis (NAE), Cotula coronopifolia (INT), Coulterella capitata (BAJ), Crassula connata var. eremica (CAL), Cressa truxillensis (WES), Croton californicus (MAD), Cryptantha leiocarpa (CAL), C. maritima var. maritima (MAD), Cupressus macrocarpa (CAL), C. salina (WES), C. veatchii (BAJ), Cynanchum peninsulare (BAJ), Cyrtocarpa edulis (BAJ), Cytisus scoparius (INT), C. striatus (INT), Dalea brandegeei (BAJ), D. divaricata subsp. anthonyi (BAJ), D. maritima (BAJ), D. mollis subsp. mollis (SON), D. tinctoria var. tinctoria (BAJ), Dendranthema arcticum subsp. arcticum (NAE), Deschampsia cespitosa subsp. beringensis (NAE), Dichelostemma capitatum subsp. capitatum (MAD), Disporum hookeri (NOA), D. smithii (PAC), Distichlis spicata (NOA), Ditaxis brandegeei var. intonsa (BAJ), D. neomexicana (MAD), D. serrata (SON), Dithyrea californica var. clinata (BAJ), Dodecatheon pulchellum subsp. macrocarpum (PAC), Drymaria holosteoides var. crassifolia (BAJ), Dryopteris arguta (WES), D. expansa (NOA), Dudleya attenuata subsp. orcuttii (CAL), D. caespitosa (CAL), D. campanulata (CAL), D. cultrata (BAJ), D. cymosa subsp. cymosa (CAL), D. farinosa (CAL), D. ingens (BAJ), D. lanceolata (MAD), D. pulverulenta (MAD), Dyssodia anthemidifolia (BAJ), D. speciosa (BAJ), Echinocereus brandegeei (BAJ), E. maritimus (BAJ), Echinopepon minimus (BAJ), Eleocharis palustris (COS), Empetrum nigrum (HOL), Encelia californica var. asperifolia (BAJ), E. californica var. californica (MAD), E. farinosa var. farinosa (SON), E. farinosa var. phenocodonta (SON), E. farinosa var. radians (BAJ), E. halimifolia (SON), E. laciniata (BAJ), E. ventorum (BAJ), Ephedra californica (MAD), E. trifurca (SON), Epilobium ciliatum subsp. glandulosum 
(NOA), E. densiflorum (WES), Equisetum hyemale var. affine (NOA), E. sylvaticum (HOL), E. telmateia var. braunii (NOA), Eragrostis hypnoides (NAS), Erechtites minima (INT), Ericameria ericoides (CAL), Erigeron blochmaniae (CAL), E. glaucus (CAL), Eriodictyon crassifolium (CAL), Eriogonum fasciculatum var. fasciculatum (CAL), E. fasciculatum var. flavoviride (SON), E. latifolium (CAL), E. parvifolium (CAL), E. confertiflorum (CAL), Eriophyllum stoechadifolium (CAL), Errazurizia megacarpa (BAJ), Erysimum franciscanum (CAL), E. insulare subsp. suffrutescens (CAL), E. menziesii subsp. concinnum (CAL), E. menziesii subsp. eurekense (CAL), E. menziesii subsp. yadonii (CAL), Eschscholzia californica (NOA), Euphorbia ceratoderma (SON), E. heterophylla var. graminifolia (NAS), E. leucophylla (SON), E. micromera (NEO), E. misera (MAD), E. polycarpa var. johnstonii (BAJ), Fagonia laevis (SON), F. pachyacantha (SON), Ferocactus cylindraceus var. cylindraceus (SON), F. fordii var. fordii (BAJ), Ferocactus gracilis var. coloratus (BAJ), F. towsendianus (BAJ), F. viridescens (CAL), Festuca rubra subsp. rubra (COS), Filago californica (WES), Foeniculum vulgare (INT), Fouquieria diguetii (SON), Fragaria chiloensis subsp. pacifica (NAS), Frankenia palmeri (MAD), F. salina (NAS), Fraxinus latifolia (PAC), F. trifoliata (BAJ), Fritillaria camschatcensis (PAC), Froelichia interrupta (NEO), Galium angustifolium (CAL), G. aparine (HOL), G. porrigens (CAL), G. trifidum subsp. columbianum (WES), G. triflorum (COS), Gaultheria shallon (PAC), Geocaulon lividum (NOA), Geranium erianthum (BOR), Glaux maritima (HOL), Glehnia littoralis subsp. leiocarpa (PAC), Gnaphalium purpureum (NOA), G. ramosissimum (CAL), G. stramineum (NOA), Goodyera oblongifolia (NOA), Grindelia hirsutula var. hirsutula (CAL), G. hirsutula var. maritima (CAL), G. integrifolia (SON), G. stricta subsp. platyphylla (CAL), Haplopappus berberidis $(\mathrm{BAJ}), H$. rosaricus $(\mathrm{BAJ}), H$. sonorensis (SON), $H$. venetus subsp. tridentatus (CAL), Harfordia macroptera (BAJ), Hazardia squarrosa var. grindelioides (CAL), Hedera helix (INT), Helenium bolanderi (CAL), Helianthus niveus subsp. niveus (MAD), Heliotropium curassavicum (NAS), H. procumbens (NAS), Hemizonia fasciculata (CAL), Heracleum maximum (NOA), Heteromeles arbutifolia (CAL), Heterotheca sessiliflora subsp. bolanderi (CAL), H. subaxillaris (NOA), Heuchera pilosissima (CAL), Hieracium albiflorum (WES), Hierochloe alpina subsp. alpina (HOL), Hippuris tetraphylla (BOR), $H$. vulgaris (COS), Hofmeisteria fasciculata var. fasciculata (BAJ), Holcus lanatus (INT), H. mollis (INT), Holodiscus discolor (NOA), Honkenya peploides subsp. major (NAE), Hordeum brachyantherum subsp. brachyantherum (NOA), H. marinum subsp. gussonianum (INT), Horsfordia alata (SON), Houstonia mucronata (BAJ), Hymenoclea pentalepis (SON), Hypericum anagallioides (WES), Hypochaeris glabra (INT), H. radicata (INT), Hyptis emoryi (SON), Ibervillea sonorae var. peninsularis (BAJ), Ipomoea costellata (NEO), I. pes-caprae (NEO), I. stolonifera (NEO), Iris douglasiana (CAL), Isocoma menziesii var. menziesii (CAL), I. menziesii var. sedoides (CAL), I. menziesii var. vernonioides (MAD), Isolepis carinata (NOA), I. cernua (COS), Isomeris arborea (MAD), Jatropha cinerea (NEO), J. cordata (BAJ), J. cuneata (SON), Jaumea carnosa (WES), Jouvea pilosa (NEO), Juglans californica (CAL), Juncus balticus (COS), J. bufonius (COS), J. falcatus (COS), J. gerardii (HOL), J. haenkey (BOR), J. lesueurii (PAC), J. phaeocephalus (WES), J. sphaerocarpus (MAD), J. supiniformis (PAC), Justicia californica (SON), Keckiella antirrhinoides var. antirrhinoides (CAL), K. cordifolia (CAL), Krameria paucifolia (SON), Laguncularia racemosa, Larrea tridentata (NEO), Lathyrus japonicus var. maritimus (NAS), L. littoralis (PAC), L. palustris (NOA), Leotondon taraxacoides (INT), Lepidium nitidum (MAD), Leymus mollis subsp. mollis (NAE), Ligusticum scoticum subsp. hultenii (BOR), Lilaeopsis occidentalis (PAC), Limonium californicum (CAL), Linnaea borealis subsp. americana (NOA), Listera convallarioides (NAE), Lithocarpus densiflorus (CAL), Lomatogonium rotatum (WES), Lonicera ciliosa (WES), L. involucrata var. involucrata (NOA), L. involucrata var. ledebourii (CAL), Lotus bryantii (BAJ), L. corniculatus (INT), L. hamatus (CAL), L. junceus var. biolettii (CAL), L. rigidus (MAD), L. salsuginosus (WES), Lotus scoparius var. scoparius (CAL), L. uliginosus (INT), Lupinus arboreus (PAC), L. chamissonis (CAL), L. concinnus (MAD), L. littoralis (PAC), L. variicolor (CAL), Luzula glabrata var. hitchcockii (WES), L. multiflora subsp. multiflora (WES), Lycium andersonii (MAD), L. berlandieri var. peninsulare (SON), L. brevipes (MAD), L. californicum (MAD), L. carolinianum (NEO), L. exsertum (SON), L. fremontii var. congestum (SON), L. megacarpum (BAJ), Lycopodium annotinum (HOL), Lysichiton americanum (WES), Maba intrincata (BAJ), Madia sativa (NAS), Maianthemum dilatatum (WES), $M$. racemosum subsp. amplexicaule (NOA), M. stellatum (NOA), Malacothamnus densiflorus (CAL), M. fasciculatus (CAL), Malacothrix incana (CAL), M. saxatilis (CAL), Malosma laurina (CAL), Malus fusca (PAC), Malvastrum coromendalianum (PAC), Mammillaria brandegeei (BAJ), M. dioica (MAD), Marah fabaceus (CAL), M. macrocarpus (CAL), M. oreganus (WES), Maytenus phyllantoides (NEO), Melica frutescens (MAD), $M$. imperfecta (CAL), Melilotus indica (INT), Mentha arvensis (HOL), Menziesia ferruginea (WES), Mertensia maritima (HOL), Mesembryanthemum crystallinum (INT), M. nodiflorum (INT), Mimulus aurantiacus (CAL), M. guttatus (NOA), Mirabilis californica (CAL), Momordica charanthia (PAC), Monanthochloe littoralis (NOA), Monardella crispa (CAL), Myosurus minimus (HOL), Myrica californica (PAC), Myrtillocactus cochal (BAJ), Nassella lepida (CAL), N. pulchra (CAL), N. speciosa (NOA), Nemacaulis denudata (MAD), Nicotiana glauca (INT), Nolina parryi (MAD), Oenanthe sarmentosa (PAC), Oenothera drummondii var. thalassaphila (BAJ), O. elata subsp. hookeri (CAL), Oligomeris linifolia (MAD), Olneya tesota (SON), Oplopanax horridus (NOA), Opuntia acanthocarpa (SON), O. cholla (BAJ), O. ganderi var. ganderi (BAJ), O. invicta (BAJ), O. littoralis (CAL), O. prolifera (CAL), O. rosarica (BAJ), O. tesajo (BAJ), Ornitostaphylos oppositifolia (CAL), Orthilia secunda (HOL), Osmorhiza berteroi (NOA), Oxalis oregana (PAC), Pachycereus pringlei (SON), P. schottii (SON), Pachycormus discolor var. veatchiana (BAJ), Palafoxia linearis var. linearis (SON), Parentucellia viscosa (INT), Parkinsonia microphylla (SON), Parnasia palustris var. palustris (HOL), Passiflora foetida var. 
longipedunculata (NEO), Pedilanthus macrocarpus (SON), Pentagramma triangularis var. triangularis (WES), P. triangularis var. viscosa (CAL), Perityle crassifolia var. crassifolia (BAJ), P. crassifolia var. robusta (BAJ), P. emoryi (MAD), Peucephyllum schottii (MAD), Phacelia argentea (CAL), P. bolanderi (PAC), $P$. distans (NOA), Phaseolus acutifolius var. latifolius (NEO), P. filiformis (SON), Phoradendron californicum (MAD), Phrygilanthus sonorae (SON), Physalis crassifolia (SON), P.Eraser Bromus glabra (BAJ), Picea glauca (NOA), P. sitchensis (PAC), Pinus contorta var. contorta (PAC), P. torreyana (CAL), Pithecellobium confine (BAJ), Plantago coronopus (INT), $P$. erecta (MAD), P. lanceolata (INT), P. maritima var. juncoides (HOL), P. subnuda (CAL), Pleuraphis rigida (SON), Poa arctica subsp. williamsii (WES), $P$. confinis (PAC), P. douglasii subsp. douglasii (CAL), $P$. eminens (BOR), P. fendleriana (WES), P. macrantha (PAC), P. macrocalyx (BOR), Polycarpon depressum (CAL), Polygonum aviculare (INT), P. hydropiperoides (NOA), $P$. paronychia (PAC), Polypodium glycyrrhiza (WES), P. scouleri (WES), Polypogon maritimus (INT), P. monspeliensis (INT), Polystichum munitum (WES), Populus balsamifera subsp. trichocarpa (WES), P. fremontii (MAD), Porophyllum gracile (MAD), P. maritimum (BAJ), P. porfyreum (BAJ), Portulaca pilosa (NEO), Potentilla villosa (PAC), Proboscidea altheaefolia (SON), Prosopis articulata (SON), P. glandulosa var. torreyana (SON), P. palmeri (BAJ), Prunus fasciculata var. fasciculata (MAD), P. ilicifolia (CAL), Pseudotsuga menziesii var. menziesii (WES), Pteridium aquilinum var. pubescens (WES), Puccinellia distans subsp. distans (HOL), P. hultenii (BOR), P. kurilensis (PAC), P. nutkaensis (PAC), P. nuttalliana (NOA), P. phryganodes subsp. phryganodes (HOL), P. tenella subsp. alascana (BOR), Pyrola picta (WES), Quercus agrifolia (CAL), Q. dumosa (CAL), Ranunculus cymbalaria (HOL), $R$. flammula var. ovalis (NOA), $R$. uncinatus (WES), Raphanus sativus (INT), Rhamnus californica subsp. californica (CAL), $R$. crocea (CAL), $R$. purshiana (WES), Rhinanthus minor subsp. groenlandicus (BOR), R. minor subsp. minor (HOL), Rhizophora mangle (NEO), Rhododendron macrophyllum (PAC), R. occidentale (PAC), Rhus integrifolia (CAL), Ribes lacustre (NOA), R. speciosum (CAL), $R$. tortuosum (BAJ), Rorippa nasturtiumaquaticum (COS), Rosa acicularis subsp. acicularis (HOL), R. minutifolia (BAJ), R. nutkana var. nutkana (WES), Rubus discolor (INT), R. lasiococcus (PAC), R. macropetalus (WES), $R$. parviflorus (NOA), R. ursinus subsp. ursinus (WES), Rumex acetosella (INT), R. arcticus (HOL), R. crispus (INT), R. salicifolius var. crassus (PAC), Sagina maxima subsp. crassicaulis (PAC), S. procumbens (NOA), Salicornia bigelovii (NAS), S. maritima (COS), Salix hookeriana (PAC), S. lasiolepis (MAD), Salsola tragus (INT), S. apiana (CAL), S. mellifera (CAL), S. munzii (CAL), Sambucus nigra subsp. caerulea (WES), S. racemosa (NOA), Sanicula crassicaulis (NAS), S. hoffmannii (CAL), Sapindus saponaria (NEO), Sarcocornia pacifica (PAC), S. perennis (HOL), Sarcostemma arenarium (BAJ), Saussurea nuda (NAE), Scaevola plumieri (PAC), Schismus barbatus (INT), Schoenoplectus americanus (NAS), S. californicus (NAS), S. maritimus (COS), S. robustus (NAS), S. tabernaemontani (COS), Scrophularia californica $(\mathrm{CAL})$, S. oregana (SON), Selaginella cinerascens (CAL), S. lepidophylla (NEO), Senecio blochmaniae (CAL), S. bolanderi (PAC), S. jacobea (INT), S. pseudoarnica (NAE), Sequoia sempervirens (CAL), Sesuvium verrucosum (MAD), Setaria palmeri (BAJ), Shepherdia canadensis (NOA), Silene californica (CAL), Simmondsia chinensis (MAD), Sisynrinchium californicum (PAC), Solanum hindsianum (SON), Solidago occidentalis (NOA), S. spathulata subsp. spathulata (CAL), S. spectabilis var. confinis (CAL), Sonchus arvensis (INT), S. oleraceus (INT), Sorbus sitchensis (WES), Spartina alterniflora (NOA), S. foliosa (PAC), Spergularia bocconii (INT), S. canadensis var. occidentalis (PAC), S. macrotheca (PAC), S. maritima (INT), S. ambigua (MAD), Sphaeralcea fulva (BAJ), Spiraea douglasii (NOA), Spiranthes romanzoffiana (NOA), Sporobolus virginicus (NEO), Stachys ajugoides var. rigida (WES), S. bullata (CAL), S. mexicana (PAC), Stegnosperma halimifolium (NEO), Stellaria calycantha (WES), S. humifusa (HOL), S. littoralis (CAL), Stenocereus gummosus (SON), S. thurberi var. littoralis (BAJ), Stephanomeria pauciflora (SON), Stillingia linearifolia (MAD), Suaeda calceoliformis (NOA), S. esteroa (CAL), S. maritima (INT), S. moquinii (NOA), S. taxifolia (MAD), Symphyotrichum chilense (WES), Symphyotrichum subspicatum (WES), Tamarix ramosissima (INT), Tanacetum camphoratum (PAC), Tetragonia tetragonioides (INT), Thuja plicata (WES), Tiarella trifoliata (WES), Tillaea erecta subsp. eremica (SON), Tiquilia plicata (SON), Toxicodendron diversilobum (WES), Trianthema portulacastrum (PAC), Trientalis europaea subsp. arctica (WES), Trientalis latifolia (WES), Trifolium arvense (INT), T. campestre (INT), T. repens (INT), T. wormskjoldii (WES), Triglochin conncinna (NOA), T. maritimum (HOL), T. palustris (HOL), Triphysaria pusilla (PAC), Triteleiopsis palmeri (SON), Trixis californica (MAD), Tsuga heterophylla (WES), T. angustifolia (COS), T. latifolia (COS), Ulex europaeus (INT), Umbellularia californica (CAL), Urtica holosericea (CAL), Vaccinium membranaceum (NOA), V. ovatum (PAC), $V$. parvifolium (WES), V. uliginosum (HOL), Vallesia glabra (NEO), Veronica americana (NOA), V. scutellata (NOA), Viburnum edule (NOA), Vicia nigricans subsp. gigantea (PAC), Viguiera deltoidea var. chenopodina (BAJ), V. laciniata (MAD), V. microphylla (BAJ), Viola sempervirens (WES), Viscainoa geniculata (BAJ), Vulpia myuros (INT), Washingtonia filifera (SON), Wislizenia refracta var. mammillata (SON), Xerophyllum tenax (WES), Xylococcus bicolor (CAL), Yucca schidigera (MAD), and Yucca valida (BAJ).

\section{Acknowledgments}

This study was made possible by an agreement between the Universidad de Alcalá and Universidad Autónoma de Baja California, and supported by grants from Agencia Española de Cooperación Internacional y Desarrollo (A/16146/08). We also thank Ana Burton (B.S.c) for help with the English translation.

\section{References}

[1] H. Walter, Vegetation of the Earth and Ecological Systems of the Geobiosphere, Springer, Berlin, Germany, 3rd edition, 1985.

[2] J. B. Hagen, "Ecologists and taxonomists: divergent traditions in twentieth-century plant geography," Journal of the History of Biology, vol. 19, no. 2, pp. 197-214, 1986. 
[3] P. Stott, Historical Plant Geography, George Allen \& Unwin, London, UK, 1981.

[4] R. H. Whittaker and W. A. Niering, "Vegetation of the Santa Catalina Mountains, Arizona. I. Ecological classification and distribution of species," Journal of the Arizona-Nevada Academy of Science, vol. 3, pp. 9-34, 1964.

[5] H. A. Gleason and A. Cronquist, The Natural Geography of Plants, Columbia University Press, New York, NY, USA, 1964.

[6] H. Qian, "Floristic analysis of vascular plant genera of North America north of Mexico: characteristics of phytogeography," Journal of Biogeography, vol. 26, no. 6, pp. 1307-1321, 1999.

[7] W. A. Weber, "Plant geography in the southern Rocky Mountains," in The Quaternary of the United States, H. E. Wright Jr. and D. G. Frey, Eds., pp. 453-468, Princeton University Press, Princeton, NJ, USA, 1965.

[8] M. Peinado, J. L. Aguirre, J. Delgadillo, and M. A. Macías, "Zonobiomes, zonoecotones and azonal vegetation along the Pacific coast of North America," Plant Ecology, vol. 191, no. 2, pp. 221-252, 2007.

[9] L. R. Dice, The Biotic Provinces of North America, University of Michigan, Ann Arbor, Mich, USA, 1943.

[10] M. Peinado, F. Alcaraz, J. Delgadillo, and I. Aguado, "Fitogeografía de la península de Baja California, México," Anales Jardín Botánico de Madrid, vol. 51, no. 2, pp. 255-277, 1994.

[11] R. G. Bailey, Description of the Ecoregions of the United States, USDA Forest Service, Washington, DC, USA, 2nd edition, 1995.

[12] D. E. Brown, F. Reichenbacher, and S. E. Franson, A Classification of North American Biotic Communities, University of Utah Press, Salt Lake City, Utah, USA, 1998.

[13] S. Rivas-Martínez, D. Sánchez-Mata, and M. Costa, "North American boreal and western temperate forest vegetation," Itinera Geobotanica, vol. 12, pp. 5-316, 1999.

[14] L. Brouillet and R. D. Whetstone, "Climate and physiography," in Flora of North America: North of Mexico, Flora of North America Editorial Committee, Ed., vol. 1, pp. 15-46, Oxford University Press, New York, NY, USA, 1993.

[15] J. Braun-Blanquet, Fitosociología. Bases para el Estudio de las Comunidades Vegetales, Blume, Madrid, Spain, 1979.

[16] S. Rivas-Martínez, "Mapa de series, geoseries y geopermaseries de vegetación de España (Memoria del Mapa de Vegetación Potencial de España)_parte I," Itinera Geobotanica, vol. 17, pp. 5-436, 2007.

[17] M. Peinado, F. Alcaraz, J. L. Aguirre, J. Delgadillo, and I. Aguado, "Shrubland formations and associations in Mediterranean-desert transitional zones of northwestern Baja California," Vegetatio, vol. 117, no. 2, pp. 165-179, 1995.

[18] V. Westhoff and E. van der Maarel, "The Braun-Blanquet approach," in Ordination and Classification of Communities, R. H. Whittaker, Ed., pp. 617-626, Dr. W. Junk, The Hague, The Netherlands, 1973.

[19] M. Peinado, J. L. Aguirre, J. Delgadillo, and M. A. Macías, "A phytosociological and phytogeographical survey of the coastal vegetation of western North America-part I: plant communities of Baja California, Mexico," Plant Ecology, vol. 196, no. 1, pp. 27-60, 2008.

[20] USDA NRCS, "The PLANTS Database, Version 3.5. Data compiled from various sources by Mark W. Skinner," National Plant Data Center, Baton Rouge, 2008, http://plants.usda.gov.

[21] I. L. Wiggins, Flora of Baja California, Stanford University Press, Stanford, Calif, USA, 1980.

[22] S. H. Gentry, "The agaves of Baja California," Occasional Papers of the California Academy of Science, vol. 130, pp. 1-123, 1978.
[23] C. B. Heiser, D. M. Smith, S. B. Clevenger, and W. C. Martin, "The North American sunflowers (Helianthus)," Memoirs of the Torrey Botanical Club, vol. 22, no. 3, pp. 1-218, 1966.

[24] G. L. Nesom, "Taxonomy of isocoma (compositae: astereae)," Phytologia, vol. 70, no. 2, pp. 69-114, 1991.

[25] T. Wielgorskaya, Dictionary of Generic Names of Seed Plants, Columbia University Press, New York, NY, USA, 1995.

[26] A. Takhtajan, Floristic Regions of the World, University of California Press, Berkeley, Calif, USA, 1986.

[27] M. Peinado, J. L. Aguirre, J. Delgadillo, and J. M. MartínezParras, "A phytosociological survey of the chionophilous communities of western North America-part I: temperate and Mediterranean associations," Plant Ecology, vol. 180, no. 2, pp. 187-241, 2005.

[28] A. M. Wiedemann and A. J. Pickart, "Temperate zone coastal dunes," in Coastal Dunes Ecology and Conservation, M. L. Martinez and N. P. Psuty, Eds., vol. 171 of Ecological Studies, pp. 53-65, Springer, New York, NY, USA, 2004.

[29] P. H. Raven, "Amphitropical relationships in the flora of North and South America," Quarterly Review of Biology, vol. 38, pp. 151-177, 1963.

[30] P. R. Crane and S. Lidgard, "Angiosperm diversification and paleolatitudinal gradients in Cretaceous floristic diversity," Science, vol. 246, no. 4930, pp. 675-678, 1989.

[31] L. Y. Budantsev, "Early stages of formation and dispersal of the temperate flora in the Boreal region," The Botanical Review, vol. 58, no. 1, pp. 1-48, 1992.

[32] B. H. Tiffney, "Perspectives on the origin of the floristic similarity between eastern Asia and eastern North America," Journal of the Arnold Arboretum, vol. 66, pp. 73-94, 1985.

[33] B. H. Tiffney, "The Eocene North Atlantic land bridge: its importance in Tertiary and modern phytogeography of the Northern Hemisphere," Journal of the Arnold Arboretum, vol. 66, pp. 243-273, 1985.

[34] A. Hallam, An Outline of Phanerozoic Biogeography, Oxford University Press, Oxford, UK, 1994.

[35] A. Graham, Late Cretaceous and Cenozoic History of North American Vegetation North of Mexico, Oxford University Press, New York, NY, USA, 1999.

[36] R. E. Latham and R. E. Ricklefs, "Continental comparisons of temperate-zone tree species diversity," in Species Diversity in Ecological Communities: Historical and Geographical Perspectives, R. E. Ricklefs and D. Schluter, Eds., pp. 294-314, Chicago University Press, Chicago, Ill, USA, 1993.

[37] D. I. Axelrod, "Evolution of the madro-tertiary geoflora," The Botanical Review, vol. 24, no. 7, pp. 433-509, 1958.

[38] J. A. Wolfe, "Some aspects of plant geography of the Northern Hemisphere during the Late Cretaceous and Tertiary," Annals Missouri Botanical Gardens, vol. 62, pp. 264-279, 1975.

[39] J. Muller, "Fossil pollen records of extant angiosperms," The Botanical Review, vol. 47, no. 1, pp. 1-142, 1981.

[40] D. I. Axelrod, "Outline history of California vegetation," in Terrestrial Vegetation of California, M. G. Barbour and J. Major, Eds., pp. 139-194, California Native Plant Society, Davis, Calif, USA, 1988.

[41] D. W. Taylor, "Paleobiogeographic relationships of angiosperms from the Cretaceous and early Tertiary of the North American area," Botanical Review, vol. 56, no. 4, pp. 279-417, 1990.

[42] Q.-Y. Xiang, D. E. Soltis, P. S. Soltis, S. R. Manchester, and D. J. Crawford, "Timing the eastern Asian-eastern North American floristic disjunction: molecular clock corroborates paleontological estimates," Molecular Phylogenetics and Evolution, vol. 15, no. 3, pp. 462-472, 2000. 
[43] M. J. Donoghue, C. D. Bell, and J. Li, "Phylogenetic patterns in Northern Hemisphere plant geography," International Journal of Plant Sciences, vol. 162, supplement 6, pp. S41-S52, 2001.

[44] J. Wen, "Evolution of eastern Asian and eastern North American disjunct distributions in flowering plants," Annual Review of Ecology and Systematics, vol. 30, pp. 421-455, 1999.

[45] B. A. Yurtsev, Problems of the Botanical Geography of Northeastern Asia, Nauka, Leningrad, Russia, 1974.

[46] M. Peinado, F. Alcaraz, and J. M. Martínez-Parras, Vegetation of Southeastern Spain, J. Cramer, Berlin, Germany, 1992.

[47] J. T. Parrish, "The palaeogeography of the opening South Atlantic," in The Africa-South America Connection, W. George and R. Lavocat, Eds., pp. 8-27, Clarendon Press, Oxford, UK, 1993.

[48] P. Goldblatt, Biological Relations between Africa and South America, Yale University Press, New Haven, Conn, USA, 1993.

[49] K. O. Emery and E. Uchupi, The Geology of the Atlantic Ocean, Springer, New York, NY, USA, 1984.

[50] P. J. Darlington, Zoogeography: The Geographical Distributions of Animals, John Wiley \& Sons, New York, NY, USA, 1957.

[51] A. G. Coates, "The geologic evolution of the Central American isthmus," in Evolution and Environment in Tropical America, J. A. Obando, Ed., pp. 21-56, University of Chicago Press, Chicago, Ill, USA, 1996.

[52] P. H. Raven and D. I. Axelrod, "Angiosperm biogeography and past continental movements," Annals Missouri Botanical Gardens, vol. 61, pp. 539-673, 1974.

[53] D. I. Axelrod, "Climate and vegetation in western North America during middle Pliocene time," Evolution, vol. 2, pp. 127-144, 1948.

[54] A. H. Gentry, "Neotropical floristic diversity: phytogeographical connections between Central and South America, Pleistocene climatic fluctuations, or an accident of the Andean orogeny?" Annals of the Missouri Botanical Garden, vol. 69, no. 3, pp. 557-593, 1982.

[55] J. Minch, E. Minch, J. Minch, and J. Ledesma Vázquez, Caminos de Baja California, John Minch and Associates, Mission Viejo, Calif, USA, 2003.

[56] D. I. Axelrod, "History of the Mediterranean ecosystems in California," in Mediterranean Type Ecosystems: Origin and Structure, F. di Castri and H. A. Mooney, Eds., pp. 225-227, Springer, New York, NY, USA, 1973.

[57] P. A. Delcourt and H. R. Delcourt, "Paleoclimates, paleovegetation, and paleofloras during the Late Quaternary," in Flora of North America: North of Mexico, Flora of North America Editorial Committee, Ed., vol. 1, pp. 71-96, Oxford University Press, New York, NY, USA, 1993.

[58] R. W. Klassen, "Quaternary geology of the Canadian Cordillera," in Quaternary Geology of Canada and Greenland, R. J. Fulton, Ed., pp. 15-96, Geological Survey of Canada, Ottawa, Canada, 1989.

[59] J. V. Matthews, T. W. Anderson, M. Boyko-Diakonow, et al., "Quaternary environments in Canada as documented by paleobotanical case histories," in Quaternary Geology of Canada and Greenland, R. J. Fulton, Ed., pp. 481-539, Geological Survey of Canada, Otawa, Canada, 1989.

[60] O. Gjærevoll, "A comparison between the alpine plant communities of Alaska and Scandinavia," Acta Phytogeographyca Suecica, vol. 68, pp. 83-88, 1980.

[61] L. Abrams, "The origin and geographical affinities of the flora of California," Ecology, vol. 6, pp. 1-6, 1925.

[62] C. E. Wood, "Morphology and phytogeography: the classical approach to the study of disjunctions," Annals Missouri Botanical Gardens, vol. 59, pp. 107-124, 1972.
[63] P. H. Raven, "The California flora," in Terrestrial Vegetation of California, M. G. Barbour and J. Major, Eds., pp. 109-138, California Native Plant Society, Davis, Calif, USA, 1988.

[64] P. H. Raven and D. I. Axelrod, "Origins and relationships of the California flora," University of California Publications in Botany, vol. 72, pp. 1-134, 1978.

[65] G. L. Stebbins and D. Major, "Endemism and speciation in the California flora," Ecological Monographs, vol. 35, pp. 1-35, 1965.

[66] M. Peinado, J. L. Aguirre, and J. Delgadillo, "Phytosociological, bioclimatic and biogeographical classification of woody climax communities of western North America," Journal of Vegetation Science, vol. 8, no. 4, pp. 505-528, 1997.

[67] M. D. F. Udvardy, A Classification of the Fitogeographical Provinces of the World, International Union for Conservation of Nature and Natural Resources, Morges, Switzerland, 1975.

[68] M. Peinado, F. Alcaraz, J. L. Aguirre, and J. M. MartínezParras, "Vegetation formations and associations of the zonobiomes along the North American Pacific Coast: from Northern California to Alaska," Plant Ecology, vol. 129, no. 1, pp. 29-47, 1997.

[69] R. A. Minnich, "Climate, paleoclimate and vegetation," in Terrestrial Vegetation of California, M. G. Barbour, T. KeelerWolf, and A. A. Schoenherr, Eds., pp. 43-70, University of California Press, Berkeley, Calif, USA, 3rd edition, 2007.

[70] C. W. Thornthwaite, "USDA atlas of climatic types of the United States, 1900-1939," 1941, Misc. Pub. U. S. Govt. Printing Office, Washington, DC, USA.

[71] A. J. Pickart and M. G. Barbour, "Beach and dune," in Terrestrial Vegetation of California, M. G. Barbour, et al., Ed., pp. 155-173, California Native Plant Society, Davis, Calif, USA, 3rd edition, 2007.

[72] G. J. Breckon and M. G. Barbour, "Review of North American Pacific Coast beach vegetation," Madroño, vol. 22, pp. 333360, 1974.

[73] M. G. Barbour, T. M. De Jong, and A. F. Johnson, "Additions and corrections to a review of North American Pacific Coast beach vegetation," Madroño, vol. 23, pp. 130-134, 1975.

[74] M. G. Barbour and A. F. Johnson, "Beach and dune," in Terrestrial Vegetation of California, M. G. Barbour and J. Major, Eds., pp. 223-262, California Native Plant Society, Davis, Calif, USA, 1988.

[75] J. W. Durham and E. C. Allison, "Geological history of Baja California and its marine faunas," Systematic Zoology, vol. 9, pp. 47-91, 1960. 

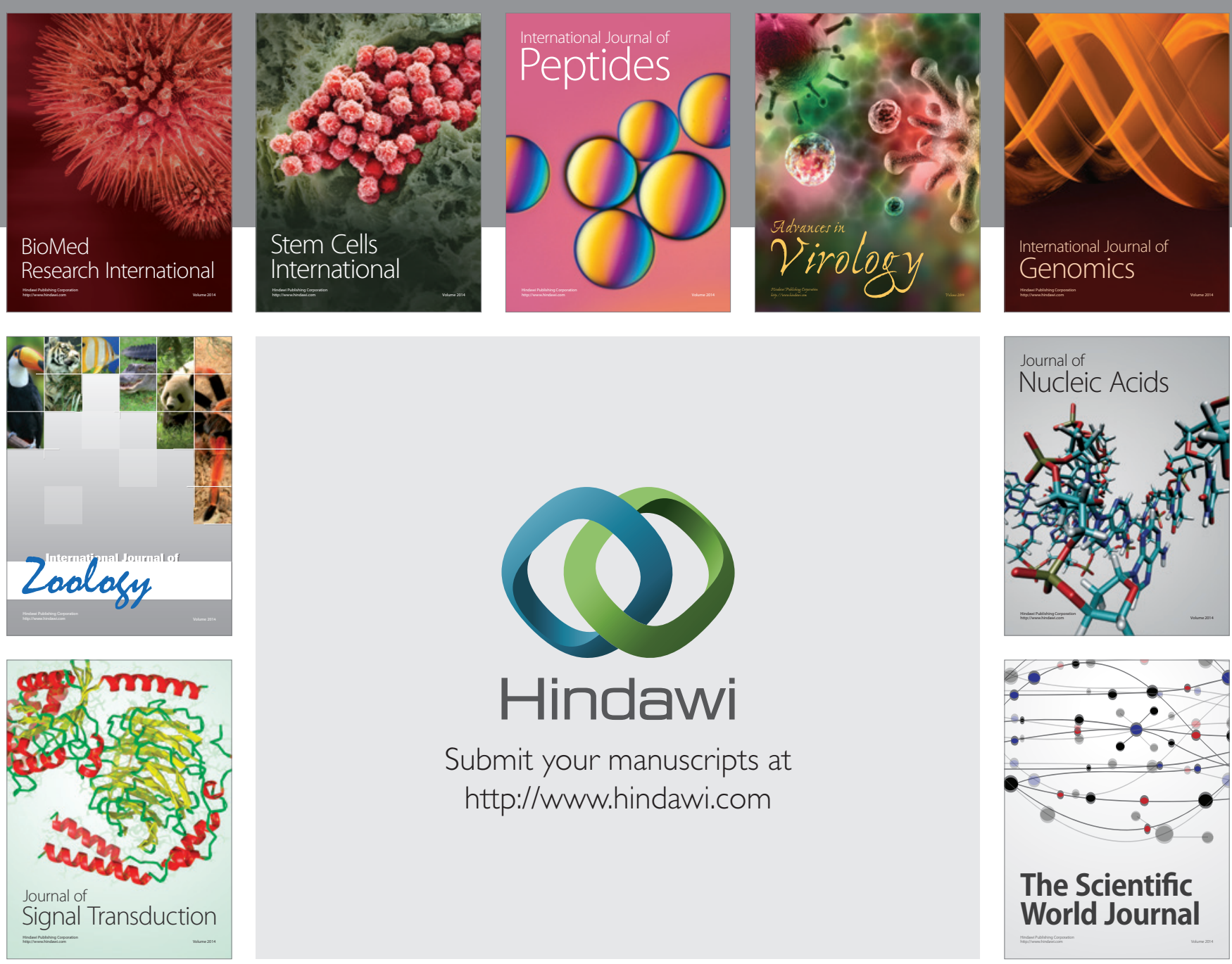

Submit your manuscripts at

http://www.hindawi.com
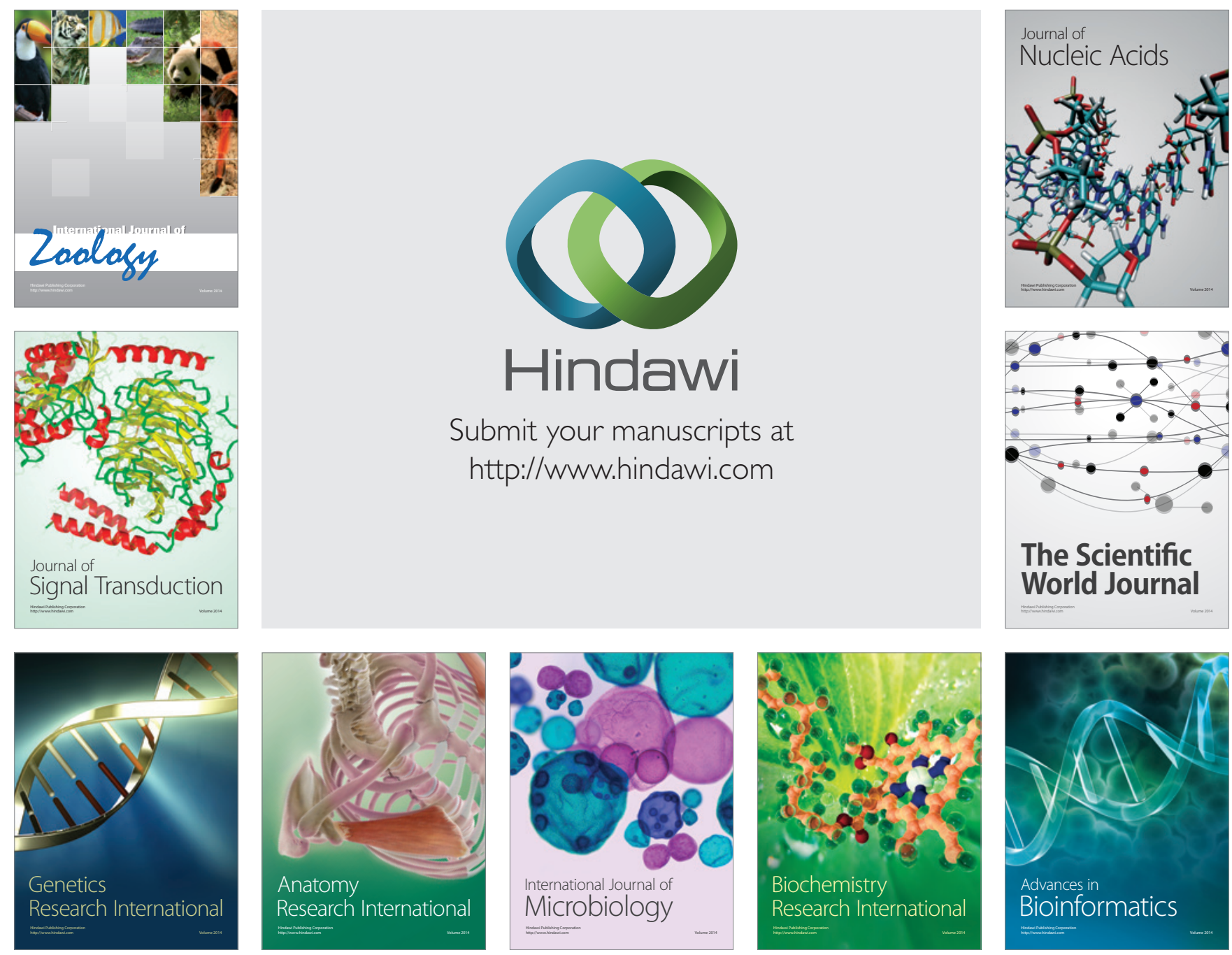

The Scientific World Journal
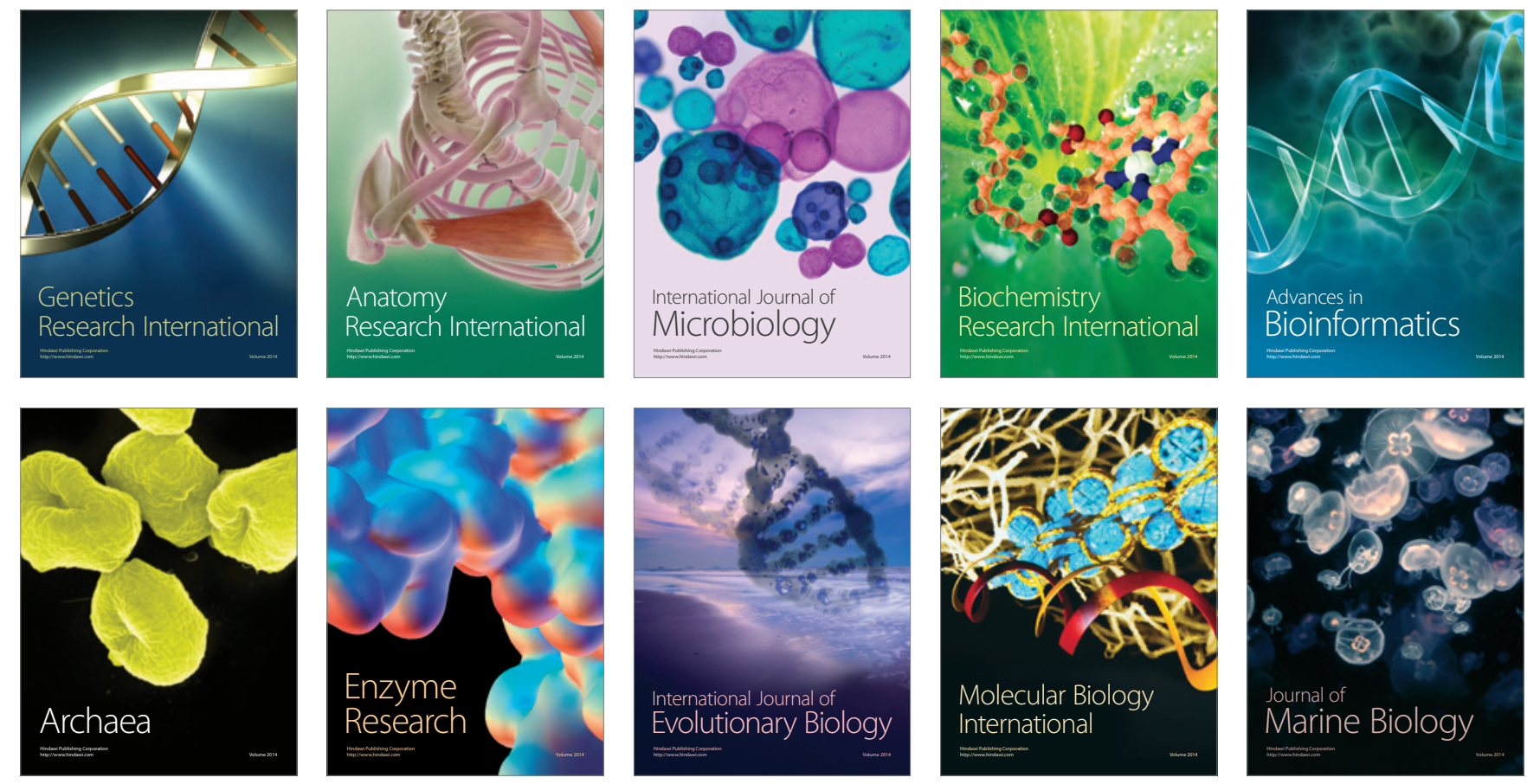